NBER WORKING PAPER SERIES

\title{
GOVERNMENT POLICY AND OWNERSHIP OF FINANCIAL ASSETS
}

\author{
Kristian Rydqvist \\ Joshua Spizman \\ Ilya A. Strebulaev \\ Working Paper 17522 \\ http://www.nber.org/papers/w17522
}

\author{
NATIONAL BUREAU OF ECONOMIC RESEARCH \\ 1050 Massachusetts Avenue \\ Cambridge, MA 02138 \\ October 2011
}

This paper has previously been circulated under the title "The Evolution of Aggregate Stock Ownership: A Unified Explanation". We are grateful for data and institutional information from Jyrki Ali-Yrkko of the Research Institute of the Finnish Economy, Masahiko Aoki of Stanford University, Jan Bjuvberg and Leif Muten of the Stockholm School of Economics, Olvind Bohren and Dag Michalsen of the Norwegian School of Management, John Comisky of the Internal Revenue Service, Shamubeel Eaqub of Goldman \& Sachs, Daniel Feenberg of NBER, Bjarne Florentsen of the Copenhagen Business School, Lucien Foldes, Carine Guilbault, Helen Katz, and Arlene Lachapelle of Canada Revenue Agency, Sebastian Herzog of the University of Mannheim, Andrew Jackson of Barclays Global Investors, Lari Kaartinen of the Finnish Central Securities Depository, Matti Kukkonen of the Swedish School of Economics, Matti Keloharju of the Finnish School of Economics and Business Administration, Lois Gottlieb of Morneau Sobeco, Riitta Ijas of the Finnish Tax Administration, Eila Laakso of Statistics Finland, Maarten Palme of Stockholm 
University, Chihiro Shima of the Development Bank of Japan, Sylvie Strobbe of Banque de France, Berouk Terefe of Statistics Canada, Kane Travers of the Taxation Statistics Administration, Daniel Waldenstrom of the Research Institute of Industrial Economics, Per-Olof Westerlund of Förhandlings- och samverkansrådet PTK, and Elaine Zimmerman of the Office of Policy \& Research. We also want to thank Rajesh Aggarwal, Franklin Allen, David Chapman, Allan Eberhart, Jennifer Huang, Clifford Holderness, Joachim Inkmann, Robert Kieschnick, Andrei Kirilenko, David Koslowsky, Sebastian Lobe, Alan Macnaughton, Alberto Manconi, Steve Schwartz, Yuzhao Zhang, and seminar participants at Binghamton, Central Florida, Copenhagen Business School, Financial Management Association 2008, German Finance Association 2008, Institute for Industrial Economics (Sweden), London Business School, McIntire School, Mid-Atlantic Research Conference 2009, Norwegian School of Economics and Business Administration, Northern Finance Association 2009, Payout Policy: Foundations and Trends at Wuppertal University, Shifting Capital Markets and Performance conference at Yale University, Texas Finance Festival 2009, UNC Tax Symposium 2008, University of Colorado at Boulder, Vanderbilt, West Virginia, Wilfried Laurier, and Washington Area Finance Association 2008 for suggestions to improve the paper. The views expressed herein are those of the authors and do not necessarily reflect the views of the National Bureau of Economic Research.

(C) 2010 by Kristian Rydqvist, Joshua Spizman and Ilya A. Strebulaev. All rights reserved. Short sections of text, not to exceed two paragraphs, may be quoted without explicit permission provided that full credit, including $(\mathbb{C}$ notice, is given to the source. 
Government Policy and Ownership of Financial Assets

Kristian Rydqvist, Joshua Spizman, and Ilya A. Strebulaev

NBER Working Paper No. 17522

October 2011

JEL No. G10,G20,H22,H30

\section{ABSTRACT}

Since World War II, direct stock ownership by households across the globe has largely been replaced by indirect stock ownership by financial institutions. We argue that tax policy is the driving force. Using long time-series from eight countries, we show that the fraction of household ownership decreases with measures of the tax benefits of holding stocks inside tax-deferred plans. This finding is important for policy considerations on effective taxation and for financial economics research on the long-term effects of taxation on corporate finance and asset prices.

Kristian Rydqvist

Binghamton University

State University of New York

PO BOX 6000

Binghamton, NY 13902-6000

and CEPR

rydqvist@binghamton.edu

Joshua Spizman

Loyola Marymount University

Hilton Center for Business

1 LMU Drive, MS 8385

Los Angeles, CA 90045-2659

joshua.spizman@1mu.edu
Ilya A. Strebulaev

Graduate School of Business

Stanford University

518 Memorial Way

Stanford, CA 94305

and NBER

istrebulaev@stanford.edu 


\section{Introduction}

Since World War II, household direct equity ownership has declined precipitously. In the United States, just after the war, households directly owned $90 \%$ of the stock market; by 2010, this figure has come down to below 30\%. The share ownership largely migrated to financial institutions that have ascended as the largest holder of equity. In 2010, domestic financial institutions owned almost $50 \%$ of U.S. stocks $1^{1}$ This long-term decline is not restricted just to the United States but spans the globe. None of the developed countries had a direct household ownership above $30 \%$ in 2005-2010, with the average around $17 \%$, and for the countries for which the historic data are available, the direct ownership numbers fifty or sixty years ago show the same steep decline. Such a structural change bears directly on the issues of corporate governance, asset pricing, effectiveness of taxation, institutional development, among many others.

Why such a big drop? A natural response of economists is that intermediaries like the mutual fund industry have taken over stock ownership due to a public demand for portfolio diversification. In this paper, however, we argue that the major force behind these changes is the two pillars of government policy: taxation and retirement regulation. Indeed, it is most likely that not only households gave up direct ownership of stocks due to associated tax benefits but the whole rise of financial intermediaries as stockholders owes largely to these two pillars. Our findings shed new light on the long-term (and likely unintended) effects of taxation on corporate finance and asset prices, demonstrate substantial path-dependence in agents' feedback to policy changes, and should be of interest to academic researchers and public policy makers alike.

The particular tax policies that have influenced stock ownership are those that on the one hand have increased effective households' income tax, and on the other have created the possibility for pre-tax savings. Such policies are fairly recent, having originated only in the first half of the XXth century in the United States. In a nutshell, when marginal income taxes are high, households prefer to save within their tax-deferred retirement plans. In addition, when tax tables are inaccurately adjusted for inflation, higher inflation increases incentives to move assets to tax-deferred accounts

\footnotetext{
${ }^{1}$ This number in fact is a substantial underestimation as it does not take into account foreign investors, most of whom are likely financial institutions.
} 
even further. These incentives have led to the rise of various financial intermediaries, such as pension funds in the United States and insurance companies in other countries. Our estimates suggest that up to $40 \%$ of all stocks in the United States - and up to $60 \%$ of stocks held by domestic agents such as mutual funds, pension funds, and insurance companies - are now kept in tax-deferred plans.

The proliferation of the mutual fund industry is one phenomenon that is better explained by the tax-related forces than by the need to diversify. Some mutual fund empirical researchers should be surprised to learn that as late as 1980, the mutual fund industry in the United States owned less than $3 \%$ of all stocks and $1 \%$ of all bonds. In the United States and other countries, mutual funds took off only when the defined-benefit retirement plans were replaced with definedcontribution plans which allow people to choose their own providers. U.S. defined-contribution plans - 401(k)s - became active only in 1982. Prior to that, over the 1950s-1970s (and particular in the 1970s when higher inflation increased tax incentives to transfer assets), a dramatic growth in institutional ownership occurred to private pensions, major beneficiaries of the defined-benefit plans. After the introduction of 401(k), mutual funds quickly increased their stock ownership share at the expense of pension funds. The same phenomenon started taking place in other countries as retirement contribution plans were instituted. In countries where defined-benefit contributions did not get instated or do not have associated tax benefits, mutual funds did not take off until very recently:2

To appreciate the difficulty of the empirical task we face, note that to provide economic underpinning for our results, using the time-series from one country is decidedly not sufficient. What is needed is the long-term panel for a reasonably large cross-section of countries where stock ownership and effective tax rates follow a different path. For most countries, historical ownership data of acceptable quality are not available. We have been able to construct long-term time series for eight countries (United States, Canada, Finland, France, Germany, Japan, Sweden, United Kingdom). For these countries, for each year we also painstakingly collected and estimated effective personal income, dividend, and capital gains taxes as well as all necessary retirement provisions. At the end,

\footnotetext{
${ }^{2}$ In many European countries, the shift from defined benefit to defined contribution schemes has not yet really started. Of the countries in our sample, Canada, Sweden, and United Kingdom adopted 401(k)-type plans around 1990, and France, Germany, and Japan in the 2000s.
} 
our panel provides substantial cross-country and time-series heterogeneity to clearly pinpoint the relationship between government policy and securities ownership. In short, the evolution of stock ownership from individuals to intermediaries is significantly related to variations in tax policy. We find that for each $1 \%$ increase in our proxy for difference in annual returns between tax-deferred and fully taxable investment, households reduce their direct stock ownership share by about 30 basis points. For the United States and Canada, we were also able to collect historical data on bond ownership, and the trend further supports the tax-retirement explanation.

Our findings have important implications both for academic research and public policy, and can explain a number of observed stylized facts. In the realm of asset pricing, stock prices would have been arguably much lower without the dynamic tax clientele shift from households to pension plans. Sialm (2009) provides supporting evidence of the relation between stock prices and effective tax rates. Stock ownership structure has important implications for corporate governance. As financial intermediaries crystalize as the largest owners of corporate equity, making them act responsibly in corporate governance matters becomes of paramount importance (see Coffee (1991), Friedman (1996), and Blackburn (2002)). In terms of public policy, personal tax has become increasingly less relevant for stock trading behavior. It is unlikely, for example, that changes in capital gains taxes in the Unites States over the past ten years had any significant impact on stock values, portfolio decisions, and economic growth. As a substantial fraction of stocks is held in tax-deferred plans, any temporary changes in tax policy are not likely to affect these variables. As long-term changes in ownership have led to a substantial loss in tax revenue, they work as a countervailing force to the original tax reforms aimed at increasing tax revenue.

Overall, our findings suggest that academic research conducted over the past few decades on the long-term effects of taxation on corporate finance and asset prices may need to be reevaluated. The implication that the changes in pension legislation and subsequent tax reforms led to long-term institutional changes in financial contracts and have in large part determined the evolution and proliferation of financial institutions as we know them today also has profound consequences for academic and public policy debates.

The paper is related to the burgeoning field of estimating the effect of taxation on corporate 
finance and asset prices. For the U.S. tax environment before 1986, Ippolito (1986) estimated as much as $40 \%$ reduction in lifetime tax liability from optimally saving inside tax-deferred plans. Important theoretical contributions to the literature on tax clienteles in the stock and bond markets include Brennan (1970) (stock market), Miller (1977) (bond market), and Auerbach and King (1983) (stock and bond market together). The empirical search for tax clientele effects has examined cross-sections of stock returns (Black and Scholes (1974), Litzenberger and Ramaswamy (1979)), abnormal stock returns around the ex-dividend day (Elton and Gruber (1970)), direct stock ownership data (Dahlquist, Robertsson, and Rydqvist (2009)), and household portfolio data from the Survey of Consumer Finances (Poterba and Samwick (2003)). Tax clientele effects are hard to detect in cross-sectional data and our paper suggest that the main piece of evidence can be found in the time-series by detecting the dynamic tax clientele shift, what Ippolito (1986) labels "the tax theory of pension funds".

The rest of the paper proceeds as follows. We start by exploring the motivating example of the United States in Section 2.1 and then discuss the mechanism of tax deferral in Section 2.2. The evolution of stock ownership is analyzed in Section 3 . Section 4 constructs independent variables, such as tax benefits of tax-deferral. Section 5.1 presents the main empirical analysis, Section 5.2 provides a number of robustness tests, and Section 6 concludes. Appendix A discusses data sources and construction of aggregate stock and bond ownership. Appendix B provides details on the tax rules in each of the sample countries.

\section{Tax Benefits of Pensions}

\subsection{Motivating Example: Evolution of the U.S. Pension and Mutual Fund In- dustries}

The development of the U.S. pension and mutual fund industries provides a vivid and potentially surprising illustration of how government policy shaped long-term financial institutional structure and induced hysteresis. It is surprising because mutual funds constitute today a large part of the financial markets and a sizeable field in financial economics has evolved over the past two decades 
Figure 1: Stock and Bond Ownership of U.S. Pension Funds and Mutual Funds

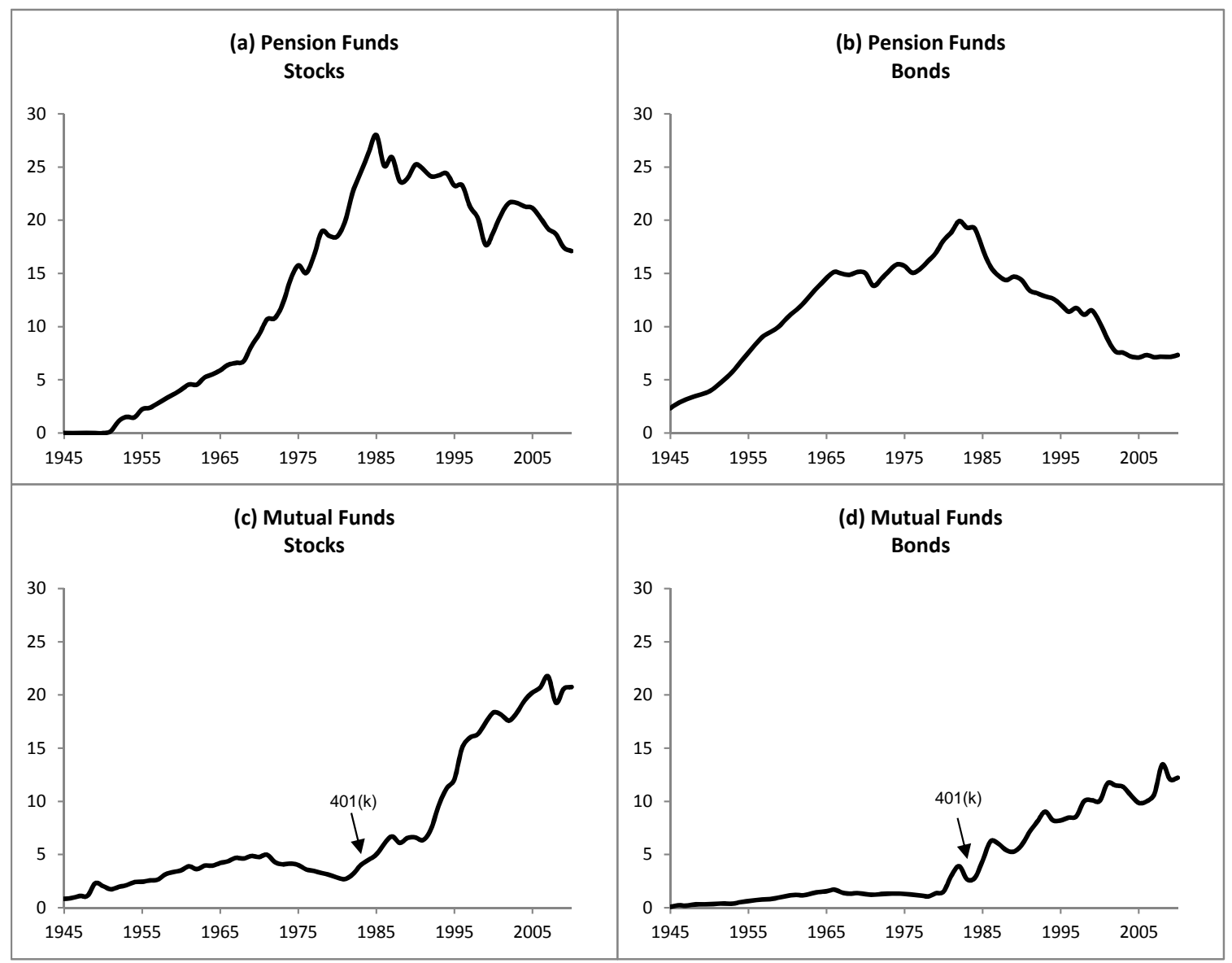

The top two figures show, respectively, the fraction of pension fund stock and bond ownership in percent of all U.S. stocks and bonds (excluding savings bonds and municipal bonds). The two figures below are the corresponding fractions of mutual fund stock and bond ownership. The two mutual fund figures also mark the introduction of 401(k) in 1982. Source: Flow of Funds. 
to study various issues related to mutual funds. As pointed out in the Introduction, as late as 1982, all the domestic mutual funds taken together owned less than $3 \%$ of all the U.S. stocks and less than $1 \%$ of all the U.S.-issued bonds. These numbers underlie the dramatic growth over these twenty years: today, it is $25 \%$ and $12 \%$ for stocks and bonds, respectively ${ }^{3}$ Importantly, most mutual fund data sets start in the 1980s, such as the CRSP Survivor-Bias-Free U.S. Mutual Fund Database that begins in 1982. Our claim is that much of this dramatic growth as well as the longterm evolution of pension and mutual fund industries, and thus, of the ownership structure of U.S. financial assets, is driven by government policy such as taxation. In this section we first describe the evolution of the mutual and pension fund industries, then provide estimates of the fraction of tax-deferred assets under the management of the mutual fund industry today, and finally sum up the economic mechanism that we believe is likely responsible for the observed correlation.

Figure 1 plots the complete time-series of stock and bond domestic ownership shares of U.S. pension funds and mutual funds. As the figure clearly shows, by the early 1980s, pension funds owned a large fraction of stocks and bonds with the peak reached in 1985 at $28 \%$ and in 1982 at $20 \%$, respectively. At the same time, mutual funds owned an insignificant fraction of stocks and bonds in 1982. From the long-term historical perspective, pension funds had been steadily growing since the late 1940s while the maximum ownership of mutual funds between 1945 and 1982 is only at around $5 \%$ for stocks and less than $2 \%$ for bonds. However, institutional arrangements for both pension and mutual funds in the United States have venerable financial and legal history. A benchmark pension fund legislation dates back to the Revenue Act of 1921 that introduced taxation of pension contracts backed by assets held by a company pension fund. The mutual fund regulation dates back to the Investment Company Act of 1940. Historical evidence allows us, however, to date the appearance of pension funds to at least the late XIXth century and mutual funds to at least 1924. Despite that, even though the popularity of pension funds kicked off in the late 1940s, mutual funds do not pick up until the mid 1980s. What is the reason for that?

An explanation that fits all these facts is based on the evolution of the way tax deferral of financial assets has been regulated over time and the extent of income taxation. Prior to the early

\footnotetext{
${ }^{3}$ Appendix A describes the methodology of constructing the ownership numbers as well as the data sources used in this section.
} 
1980s, the dominant form of tax-deferred saving was via defined-benefit plans that was managed by pension funds as Figure 1 demonstrates. As we detail in Section 4.3 , even though the pension fund legislation dates back to 1921, the regime of high effective tax rates started only in the first half of the 1940s giving rise to the proliferation of pension funds around that time. The tax-related government policies had a long-lasting impact on the evolution of the pension fund industry.

The 401(k) legislation, enacted in 1978, paved the way for the widespread adoption of definedcontribution plans. However, it became operational only in 1982 after the Economic Recovery Tax Act of 1981 (ERTA 1981) that specified the contribution limits for 401(k) plans. This legislation naturally made mutual funds carry two important economic factors that pension funds could not do. First, 401(k) accounts are driven by individual employee decisions and are thus built through payroll deductions collecting small and frequent contributions. That makes pooling small transactions in one fund beneficial from the point of view of economizing on transaction costs, and this naturally gives rise to mutual funds. Second, defined benefit plans are not portable in that it is difficult to transfer them between jobs and thus they are costlier to employees. Specifically, defined benefit plans are not portable because they are based on the final salary at age 65. (Thus, a worker who leaves prematurely will receive a small pension compared to a worker who hangs on until age 65.) The 1978 and 1981 reforms created demand for defined-contribution plans managed by mutual funds from both employers and employees and correspondingly reduced demand for pension funds.

As Figure 1 shows, there is a dramatic growth in domestic stock and bond ownership managed by mutual funds since the mid 1980s. Of course, for our purposes the major question is: What fraction of these are actually held in tax-deferred accounts? In the absence of precise numbers, the following back-of-the-envelope estimation is telling. As of 2009, which is the latest data point we have from Investment Company Institute (ICI (2010)), the aggregate value of tax-deferred investments in mutual funds held inside retirement accounts equals $\$ 2,300$ billion in stocks (Figure 12; sum of the domestic stock mutual funds and $70 \%$ of hybrid funds) and $\$ 1,200$ billion in bonds (sum of the domestic bond mutual funds and 30\% of hybrid funds). In 2009, Flow of Funds Table L.122 reports that mutual funds manage approximately $\$ 4,100$ billion in stocks and $\$ 2,700$ billion in bonds. Dividing the ICI numbers with the Flow of Funds totals, we see that the tax-deferred 
portion of stock mutual funds equals to $2,300 / 4,100=56 \%$ and bonds $1,200 / 2,700=44 \%$.

Our main message here is simple: the fraction of tax-deferred assets managed by mutual funds, even using conservative estimates which are unlikely to overestimate the fraction significantly, is economically very large, with direct economic implications such as the sensitivity of investors' behavior to the twists in the taxation of dividends and capital gains.

The example of the U.S. pension and mutual fund industries provides an illustration that government policy may have been the driving force behind the evolution of financial institutions, specifically the rise and changing nature and influence of various types of financial intermediaries. A natural and first-order explanation of the dramatic rise of mutual funds, overlooked by the generation of financial economists, lies in tax and pension government policies. To sum up, our claim is that the existence not only of pension but also of mutual funds as we know them owes much to the government tax and pension legislation driven by the then contemporary economic forces but having long-term consequences.

Although these examples are telling, we need systematic evidence to relate the ownership of financial assets to tax-related policies. For this, the data from the United States are not sufficient because it provides us with only one time-series with insufficient time series variation. Therefore, we proceed by carefully constructing two data sets: one, of marginal personal tax rates for a number of countries, and, two, the evolution of ownership of financial assets for the same crosssection of countries. This will allow us to study tax-ownership patterns for a multi-country panel. We also need to understand better the exact economic mechanisms through which tax deferral is beneficial because understanding such mechanisms will enable us to construct empirical proxies for our empirical analysis. The next section accomplishes that task.

\footnotetext{
${ }^{4}$ An alternative estimation is as follows. Pension funds manage simultaneously defined benefit plans and 401(k)type accounts (e.g., TIAA-CREF). The latter are outsourced to the mutual fund industry. From Flow of Funds, Tables L.118-120, we see that, in 2009, pension funds have $\$ 2,000$ billion invested in mutual fund shares. Dividing this number by the mutual fund total gives us $2,000 / 6,800 \approx 30 \%$. Hence, assuming that pension funds invest proportionally in stock and bond mutual fund shares, $30 \%$ is an absolutely minimum estimate of the tax-deferred portion of stock mutual fund shares through pension funds. From ICI, Figure 4, we know that $\$ 2,000$ worth of IRAs are invested in mutual funds. Adding this number and keeping the proportionality assumption, our estimate of the tax-deferred portion becomes $4,000 / 6,800 \approx 60 \%$. These numbers are consistent with Poterba and Samwick (1995) who state that two thirds of mutual fund assets are tax deferred. Sialm and Starks (2010) report an average tax-deferred fraction of $25 \%$ taking an equally-weighted average.
} 


\subsection{Economic mechanisms of tax deferral}

In this section, we present the simplest stylized setting that allows us to explain two economic mechanisms that provide benefits of tax deferral, namely, income smoothing and untaxed investment income. Despite its simplicity, our setting is nevertheless applicable as a rough first approximation to understand the principles of tax deferral. As an example, in the United States, according to the principles for the taxation of pensions that date back to the Revenue Act of 1921, which states that employer and employee contributions to private pension plans are made before tax, investment returns grow tax free, and distributions are taxed as personal income 5 In the parlance of public economics, tax deferral implies the consumption-tax treatment of pensions as opposed to the income-tax treatment of regular savings, where contributions are taxed at the time of investment, investment returns are taxed upon realization, but distributions are exempt from personal tax.

To illustrate the argument in the simplest possible way, suppose there is only one risk-free asset in the economy and all the parameters are known constants. An individual chooses between saving inside or outside a pension plan. The annual rate of return is $r$ and the time to retirement is $N$ years. Personal income is taxed at rate $\tau_{0}$ when it is earned and at rate $\tau_{w}$ when it is withdrawn. Investment returns outside the pension plan are taxed at rate $\tau_{i}, i=1, \ldots, N$.

Consider an individual who decides to set aside $\$ 100$ pre-tax money for retirement. If he invests outside the pension plan, the after-tax payoff after $N$ years equals:

$$
W_{S}=\left[100\left(1-\tau_{0}\right)\right] \times\left[1+r\left(1-\tau_{i}\right)\right]^{N}
$$

Equation (1) shows that savings are taxed at rate $\tau_{0}$ when income is earned and at rate $\tau_{i}$ when capital income is reinvested. Hence, household savings outside the pension plan are taxed twice. Alternatively, if the individual saves inside the pension plan, the after-tax payoff after $N$ years equals:

$$
W_{P}=\left[100(1+r)^{N}\right] \times\left(1-\tau_{w}\right) .
$$

\footnotetext{
${ }^{5}$ The consumption-tax treatment of funded pension schemes appears to be the general principle across countries. France has an unfunded private pension plan (pay as you go) that is an exception.
} 
Contributions to the pension plan can be made with pre-tax money, investment returns grow tax free, and distributions are taxed at rate $\tau_{w}$. Hence, savings inside the pension plan are taxed only once. Equations (1) and (2) are equal and the individual is indifferent between saving outside or inside the pension plan if $\tau_{0}=\tau_{w}$ and $\tau_{i}=0$ for all $i$.

This implies that saving inside the pension plan offers two potential tax benefits. First, the individual benefits from income smoothing when the tax schedule is progressive and $\tau_{0}>\tau_{w}$, i.e., the individual reduces his lifetime tax burden by saving when income is high and withdrawing when income is low. Second, investment returns inside the pension plan grow tax free, $\tau_{i}=0$.

This simple argument abstracts from a number of realistic features, some of which we identify here. Although we do not explicitly account for corporate tax, it does not matter in most countries because wages and contributions to private pension funds are both tax deductible expenses for the firm ${ }^{6}$ It also does not account for other taxes such as social security taxes which add an additional benefit to tax deferral because they affect Equation (1) but not Equation (2) 7 It also ignores uncertainty in asset returns as well as in retirement age even though both can be relatively easily added 8 Because our argument considers only one asset, we also ignore the asset location problem. As argued in a series of important papers (Dammon, Spatt, and Zhang (2004) and Huang (2008)), tax incentives can tilt the tax-deferred account towards bonds and taxable accounts towards stocks. Empirically, we know (see Appendix A that in the aggregate, the stock-bond split in U.S. pension fund portfolios is 70/30, and 70\% of households' tax-deferred assets are in stocks (according to Bergstresser and Poterba (2004), based on the Survey of Consumer Finances 1998). As such, there is a strong preference for stocks inside these accounts and, therefore, even though such tilting may constitute an important economic activity, it is unlikely to invalidate the two economic mechanisms

\footnotetext{
${ }^{6}$ In Germany, Japan, and Sweden, where pension liabilities are held on the books, contributions are made before tax, but corporate tax must be paid, when the book reserves are dissolved. Hence, corporate tax is deferred along with personal tax.

${ }^{7}$ Contributions to the Social Security system are levied on wages, but not on employer contributions to private pension plans. Escaping social security tax is, therefore, an additional tax benefit of saving inside a pension plan that we ignore. Social security taxes are capped and, therefore, irrelevant at higher income levels that matter more for contributions to private pension plans. There are exceptions. In the United States, the cap on payments into the public health system (Medicare) was removed in 1990 and in Sweden, where social security tax rates are quite high, the cap on social security contributions was removed in 1968.

${ }^{8}$ The net effect of interest rate uncertainty is ambiguous. Interest rate uncertainty increases the income from indirect ownership because $W_{S}$ and $W_{P}$ are convex functions. On the other hand, interest rate uncertainty increases the volatility of income because the variance of before-tax income is higher than the variance of after-tax income.
} 
we describe.

\section{The Evolution of Stock Ownership}

Our main goal is to relate the long-term changes in the structure of ownership of financial assets to government policies such as taxes and pension legislation. Accomplishing this goal requires crosscountry analysis to explore the time-series variation in government policies. Although the raw historical data on personal tax legislation is available for a wide array of countries, the long-term data on ownership are much more difficult to come by. Therefore, in our analysis we are guided by eight countries for which we were able to find and construct the data on long-term stock ownership 9 In this section, we provide the overall description of the long-term evolution of the distribution of stock ownership in the sample countries. The main finding of this descriptive section is that the direct ownership of stocks by households has declined precipitously over the past half a century in all eight sample countries and has been picked up to a large extent by financial institutions.10

Importantly, although we concentrate only on eight countries, existing data for recent years for a much wider range of countries provide corroborative evidence for this finding. Figure 2 summarizes the fraction of direct household ownership in recent years for twenty countries with developed stock markets. There is not a single country where households own more than $30 \%$ of the equity market directly, with the average across countries being just 17\%. As can be seen from the figure, our sample covers the whole spectrum of current ownership structure, from $4.7 \%$ in Norway to $28.3 \%$ in Canada.

We first discuss how we constructed and adjusted ownership data to make cross-country com-

\footnotetext{
${ }^{9}$ We were able to find relatively short-term series for various other countries (Norway 1985-2006; Australia 19882006; Italy 1995-2006) but the series were too short to be included in the analysis.

${ }^{10} \mathrm{~A}$ natural extension of our study would be look at the evolution of the household bond ownership. One may conjecture that direct bond ownership should decline substantially in line with the stock ownership. However, we were able to find the high-quality long-term historical bond ownership data only for the United States (and a shorter series for Canada starting in 1961) The main feature of the U.S. bond ownership time series is that households own less than $10 \%$ of the total bond market since the start of the World War II when massive bond issuance by the U.S. government was absorbed by banks. Households' direct bond ownership remains low ever since. For example, over the past twenty years, excluding our estimates of non-profit ownership and bond ownership in IRA accounts, household direct ownership of taxable debt is in the range of about $10 \%$. Given very low values of this variable throughout the whole period, there is no room for a response to tax incentives. The Canadian data are consistent with this analysis. Details are available from the authors upon request.
} 
Figure 2: Households' Direct Ownership Fraction of Stocks

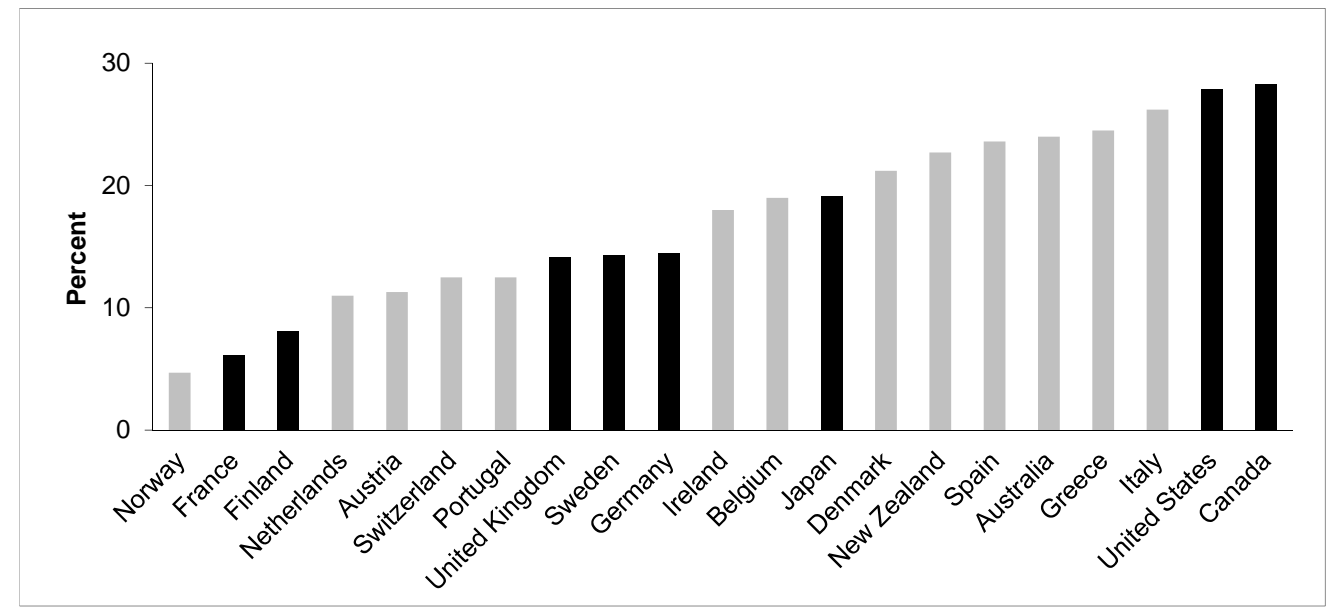

The figure shows the aggregate fraction of household direct ownership of equity in 21 countries. The data are from 2006 or the most recent available; the data for the United States are from 2010. The black bars indicate the country is in our data set. Data sources: Flow of Funds (United States), Statistics Canada, Australian Bureau of Statistics, FESE (2007), Goldman \& Sachs (New Zealand), and Nordic Central Securities Depository (Finland and Sweden). The number for the United States has been adjusted for the ownership of closelyheld firms and non-profit organizations. The number for Canada has been adjusted for closely-held equity.

parisons possible. Then, we analyze the data by studying the extent of the decline in household direct ownership and exploring common patterns of stock ownership evolution.

\subsection{Stock Ownership Data}

Annual ownership statistics exist for the United States since 1945, Japan 1949, Germany 1950, Canada 1961, and France 1977. Time-series of ownership data for Sweden begin 1950, United Kingdom 1957, and Finland 1958, but data are incomplete and only available for some years.11

The U.S. ownership data are constructed by the Federal Reserve 12 The direct household ownership is estimated as a residual in a calculation which starts with the market value of listed stocks, adds an estimate of the book value of non-listed stocks, eliminates inter-corporate ownership, and subtracts the ownership of domestic financial institutions and foreigners. Even though this residual

\footnotetext{
${ }^{11}$ All data sources can be found in the notes of Figures $3 \mathrm{a}$ and $3 \mathrm{~b}$

${ }^{12}$ Reported in the Flow of Funds. One additional issue we have encountered in using the U.S. ownership data is that the Federal Reserve tends to revise its estimates, at times to a non-trivial extent. The data we use are based on the 2010 version of the data.
} 
is labeled by the Federal reserve as the "household sector," it contains non-listed stocks as well as ownership of non-profit organizations and thus is likely upward biased relative to the fraction of direct household ownership reported in the data for other sample countries ${ }^{13}$ The bias arising from non-listed stocks can be estimated from the difference between the Flow of Funds total and stock market capitalizations, and the ownership of non-profit organizations is available from 1987-2000 (Table L.100a). To make the U.S. data comparable to that of other sample countries, we use the adjusted household sector ownership by subtracting the value of non-listed stocks and our estimate of the ownership of non-profit organizations. Non-listed stocks and non-profit organizations account for approximately four percentage points each of the household sector. Correcting for these biases, the fraction of household ownership in the United States is $30 \%$ as of $2006{ }^{14}$ It is important to note that in our regression analysis in Section 5.1, the dependent variable is the change in household ownership, and thus all these adjustments have no influence on the results.

The Canadian ownership shares are constructed as in the United States except that the total is defined as the book value of listed and non-listed stocks. The household sector is derived as the residual and consists of actual households and non-profit organizations. Therefore, the Canadian household sector is also upward biased. The book value of listed and non-listed stocks exceeds the market value of listed stocks by $26 \%$ over the 1980-2005 period. Therefore, we adjust the fractions from Statistics Canada by the overshooting $26 \%$. Specifically, for households, we subtract 0.26 from the observed fraction of household ownership and divide by 0.74 . For all others sectors, we divide the observed fraction of ownership by 0.74 . The adjusted fraction of household ownership in 2006 is $28.3 \%$. Inter-corporate ownership is explicit, but quite small.

The Japanese ownership shares are reported as fractions of the number of shares outstanding before 1970 and as fractions of market values from 1970 onwards. Given that households tend to hold a larger share of small cap stocks, the aggregate household ownership share in 1949-1970 is likely to be overestimated. For the United Kingdom, Germany, France, and Sweden, the ownership shares are fractions of market values. The UK ownership statistics are based on company surveys

\footnotetext{
${ }^{13}$ The Federal Reserve estimate is also in principle biased downwards because it eliminates inter-corporate ownership. However, it is likely this bias is very small.

${ }^{14}$ Poterba and Samwick (1995) and French (2008) make further attempts to adjust the household sector.
} 
with the most recent ownership statistics from the share registry. The official share registry is also the basis for the ownership statistics from recent years in Sweden (since 1975) and Finland (since 1994). The older data from Sweden and Finland are compiled using a variety of methods 15

An important caveat is that in all countries direct household ownership includes insider/managerial ownership, which ideally for our purposes we would have liked to exclude. Some estimates for the Unites States between 1993 and 2004 suggest that insider ownership is around 7\% 16 The problem is that the extent of insider ownership as well as the forms it takes are likely to be different across our sample, which our data do not allow us to adjust for.

\subsection{The Evolution of Stock Ownership}

Figures $3 \mathrm{a}$ and $3 \mathrm{~b}$ plot the complete time-series of household and institutional ownership (pension funds, investment funds, and insurance companies) for the sample countries (the composition of the institutional variable for each country is given at the bottom of the figures) 17 We use different symbols, diamonds versus lines, to mark the merger of time-series with different qualities. Households are represented by solid diamonds and solid lines, and financial institutions by open diamonds and dashed lines. Several observations stand out.

First, in all countries the long-term decline of direct household ownership is dramatic, from around $20 \%$ in Germany and Canada to above 50\% in Sweden, the United Kingdom, and the United States. The equally-weighted average of the decline across all the countries is $40 \%$. Second, a substantial fraction of household-owned assets is picked up by financial institutions. The average increase in domestic financial institutions' ownership is $24 \%$. Not shown in the figures, the rest of household ownership is shifted mostly to foreigners (who are mostly financial institutions), especially after the removal of capital controls in the 1980s and early 1990s (OECD (2002)). ${ }^{18}$ Third, there

\footnotetext{
${ }^{15}$ Sweden: the 1950 data are based on a survey of household finances by Statistics Sweden. The 1961 and 1970 data are computed as the residual from point estimates of the portfolios of financial institutions and business corporations. The ownership fractions are based on market values. Finland: the 1958 data are based on tax-assessed values, the 1972 data on market values, and the 1980-1986 data on nominal share values.

${ }^{16}$ Authors' own estimates based on manually collected proxy data for S\&P1500 firms using the EDGAR data service.

${ }^{17}$ We decided to report unadjusted values for the United States because the long-term series of non-profit ownership is not available. This accounts for the discrepancy between Figures 2 and $3 \mathrm{a}$

${ }^{18}$ Capital controls in most developed countries were adopted in preparation for or during World War II or in the immediate reconstruction period after the war. Canada removed its capital controls in 1951 and Germany in 1958.
} 
Figure 3a: Evolution of Stock Ownership

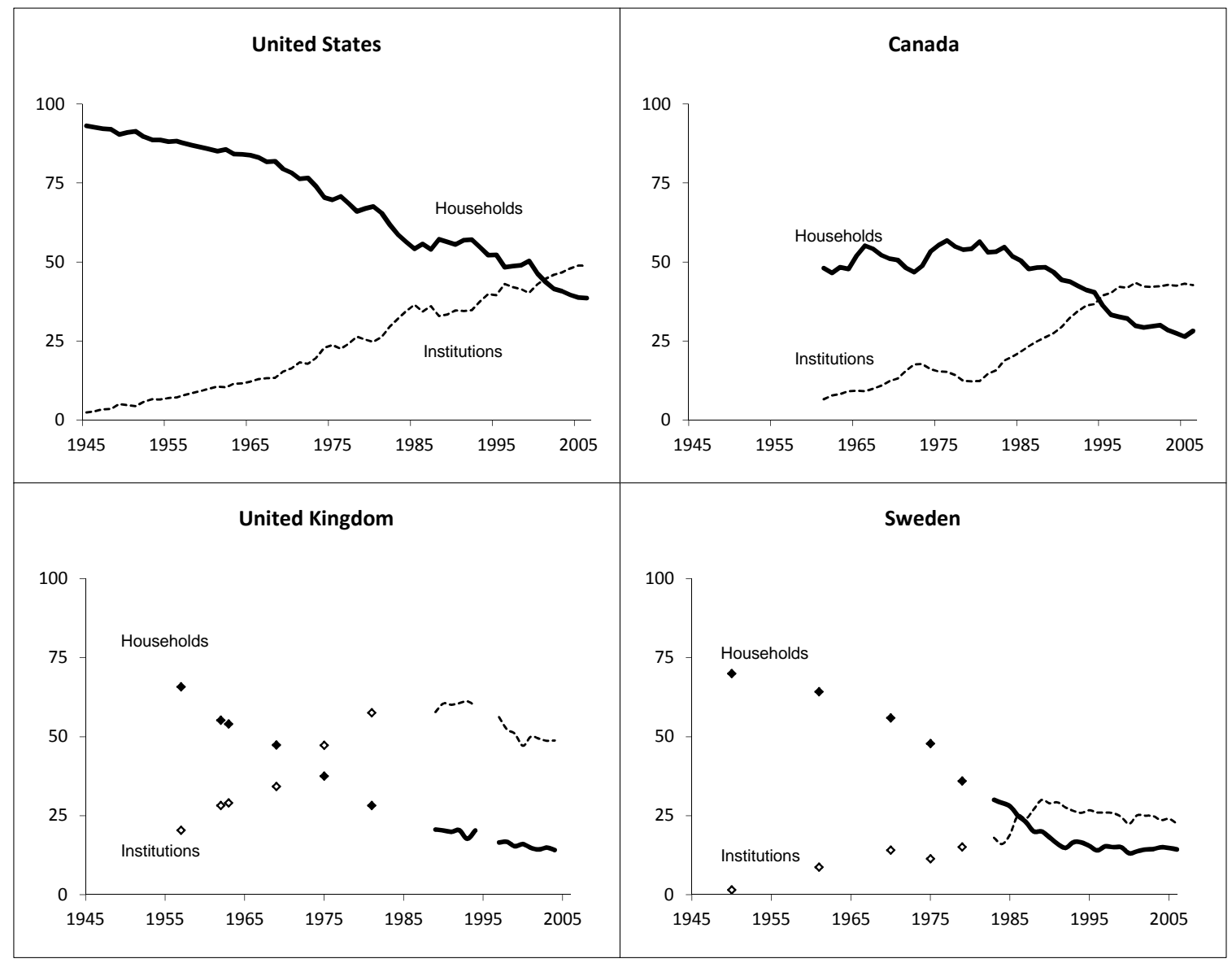

The figure shows the percentage aggregate ownership fraction of households (solid diamonds and lines) and financial institutions (open diamonds and dashed lines) defined as pension funds, mutual funds, and either life insurance companies or property and life insurance companies combined. In Canada, we also include Social Security funds and, in Sweden, investment and holding companies. Data sources: Flow of Funds (United States); Statistics Canada; Revell and Moyle (1966), Moyle (1971), and Statistics United Kingdom; Spånt (1975), Boman (1982), and Statistics Sweden. 
Figure 3b: Evolution of Stock Ownership

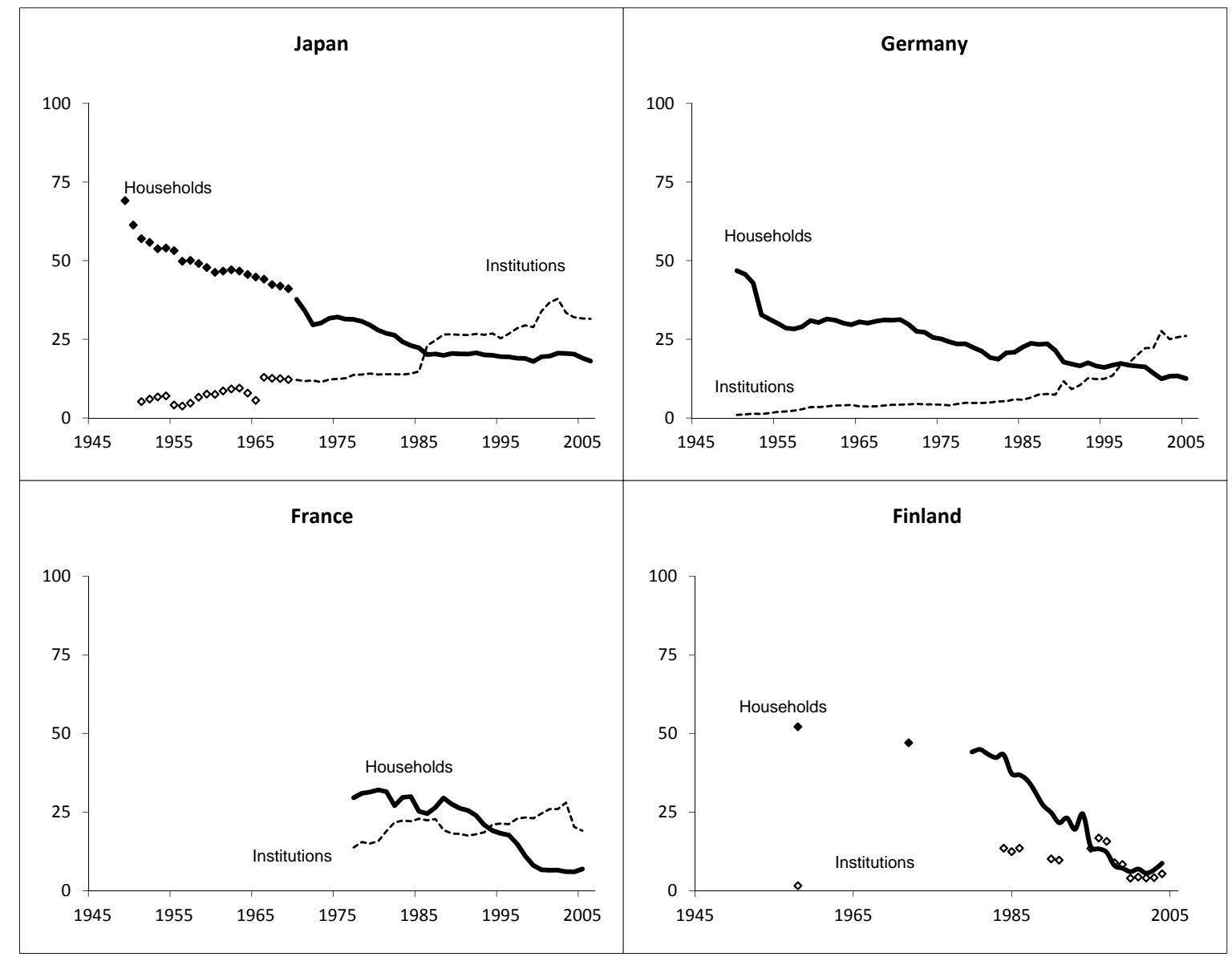

The figure shows the percentage aggregate ownership fraction of households (solid diamonds and lines) and financial institutions (open diamonds and dashed lines) defined as pension funds, mutual funds, and either life insurance companies or property and life insurance companies combined. In Japan, financial institutions include trust banks, investment trusts, annuity trusts, and insurance companies. Data sources: the Shareholder Survey and the Fact Book of the Tokyo Stock Exchange (Japan); Deutsches Aktieninstitut (Germany); Bank of France; Grandell (1959), Laakso (1979), Airaksinen and Kallinen (1987), Karhunen and Keloharju (2001) (Finland). 
is substantial within-panel heterogeneity. To see this further, Table 1 reports for each country the average decline in the fraction of household ownership per year for the whole period as well as for three subperiods. As the table clearly demonstrates, the panel exhibits heterogeneity both across time (decline in the 1970s-80s is larger in most countries than in other decades) and across countries in each subperiod.

Table 1: Annual Change in the Fraction of Household Ownership

\begin{tabular}{|c|c|c|c|c|}
\hline & \multirow[b]{2}{*}{$1945-2010$} & \multicolumn{3}{|c|}{ Sub-periods } \\
\hline & & 1950-1969 & 1970-1989 & $1990-2010$ \\
\hline Sweden & -0.99 & -0.69 & -1.84 & -0.34 \\
\hline United Kingdom & -1.10 & -1.53 & -1.34 & -0.43 \\
\hline United States & -0.88 & -0.57 & -1.15 & -0.97 \\
\hline Finland & -0.94 & -0.36 & -1.05 & -1.23 \\
\hline Japan & -0.86 & -1.40 & -0.92 & -0.14 \\
\hline Germany & -0.62 & -0.83 & -0.48 & -0.56 \\
\hline France & -0.81 & n.a. & -0.17 & -1.29 \\
\hline Canada & -0.32 & 0.28 & -0.16 & -0.80 \\
\hline \#Observations & 396 & 110 & 152 & 134 \\
\hline
\end{tabular}

The table shows the annual change in the fraction of household ownership in percent of stock market capitalization. The countries have been sorted from low to high in the 1970-1989 column.

\section{Empirical Analysis of Tax Benefits}

This section provides estimates of annual tax benefits of pensions for eight countries in our sample (Canada, Finland, France, Germany, Japan, Sweden, United Kingdom, Unites States) over long periods of time. We choose the panel to match the stock ownership data the availability of which over the long horizon is constrained to these eight countries. We start by constructing proxies that capture the two economic mechanisms outlined above. Then we proceed by describing the estimation of marginal tax rates and presenting the time-series of these tax rates for each country

The United States had capital controls in place during the Vietnam War (1963-1973). The process of removing capital controls began in the United Kingdom in 1979 and continued in Japan 1980, France 1986, Sweden 1989, and Finland 1991. 
in the sample. Finally, we present and discuss the time series of tax benefits of pensions for each country, which is the main goal of this section.

The soundness of our empirical analysis to a large extent depends on the quality of understanding the rules of how dividends and capital gains are taxed to construct the reliable and consistent measures of marginal tax rates, and thus our empirical proxies of the tax benefits. To construct the tax benefit data set, we used historical tax tables for each country in the sample, taking into account the specific features of treatment of personal income taxation for each country and each year. Appendix $\mathrm{B}$ provides detailed discussion of our data sources and, for each country, it lists the formulas we used to construct all tax-related variables.

\subsection{Empirical Proxies}

\subsubsection{Tax-Exempt Investment Income}

A good empirical proxy of the benefit of avoiding tax on investment income should reflect the difference between the real rate of return from holdings assets inside and outside the pension plan. Because investor care about real returns, but taxation is virtually always on nominal returns, it is important to adjust any tax-induced differences in returns by expected inflation. Although tax benefits will accrue to any taxable asset, because our cross-country data is mostly on stocks, we tailor our proxy to reflect return from holding stocks.

Let $d$ be the expected dividend yield, $g$ the expected capital gains rate, and $\tau_{d}$ and $\tau_{g}$ the marginal tax rates on dividends and capital gains, respectively. The expected rate of return from holding stocks inside the pension plan is:

$$
r_{P}=(1+d)(1+g)-1 \approx d+g,
$$

and the expected rate of return from direct stock ownership outside the pension plan is:

$$
r_{S}=\left[1+d\left(1-\tau_{d}\right)\right] \times\left[1+g\left(1-\tau_{g}\right)\right]-1 \approx\left(1-\tau_{d}\right) d+\left(1-\tau_{g}\right) g
$$

If $i$ denotes the expected inflation rate, then the proxy, that we denote GAP, is naturally the 
difference between $r_{P}$ and $r_{S}$, adjusted for inflation:

$$
\mathrm{GAP}=\frac{\tau_{d} d+\tau_{g} g}{1+i}
$$

It is important to note that because capital gains taxation is nominal, expected inflation is implicitly also present in the capital gains growth rate $g$. Also, taxation on nominal income implies that inflation pushes taxpayers over time into higher marginal tax brackets (commonly known as "bracket creep") and thus may change the identity of the marginal tax payer, an important empirical feature.

\subsubsection{Income Smoothing}

A proxy for income smoothing should reflect tax benefits from shifting income from high-income work years to low-income retirement years. These tax benefits are larger for more progressive tax systems. To construct a simple proxy capturing this effect, we consider a constant lifetime income model under certainty (Ippolito (1986)). Also, to isolate the pure effect of income smoothing, we assume zero risk-free interest rate 19 Specifically, assume that an individual works $N$ years and needs retirement income for $M$ years. Let $Y$ denote his annual income and $T(Y)$ the total tax liability on this income. Under a progressive tax system, tax liability is minimized when the individual chooses the same pre-tax income rate $\phi=N /(N+M)$ throughout his lifetime. Figure 4 shows an example where the number of work years is $N=40$, time in retirement is $M=13$ years, and annual income during work years is normalized at $Y=1$. Smoothed over lifetime, annual income decreases to $\phi Y=13 / 53 \approx 0.75$.

If the individual makes regular savings outside the pension plan, his lifetime tax liability equals:

$$
T_{S}=N \cdot T(Y)
$$

If instead the individual saves inside the pension plan, his annual tax liability is reduced to $T(\phi Y)$

\footnotetext{
${ }^{19}$ The assumptions of certainty and zero interest are inconsequential because the only effect is to shift the level of the smoothing benefit and we are interested in relative comparisons across country and time. A more volatile income stream as well as a growing income stream will make our proxy larger, and positive interest will make it smaller.
} 
Figure 4: Life-Cycle Consumption Model

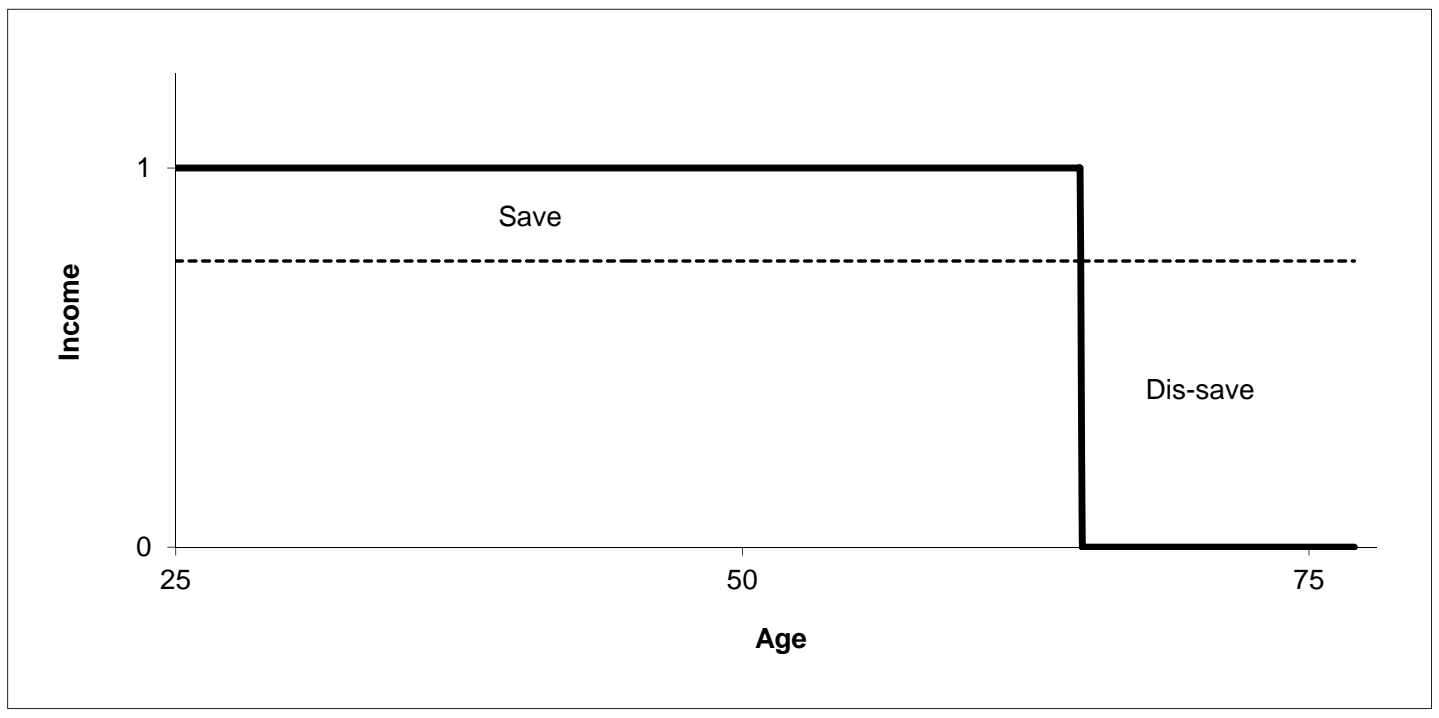

The figure shows annual pre-tax income (solid line) during work years and annual pre-tax income if smoothed over work and retirement years (dashed line).

and so the lifetime tax liability becomes:

$$
T_{P}=(N+M) \cdot T(\phi Y) .
$$

The proxy for income smoothing, that we denote SMOOTH, can naturally be constructed as the difference in lifetime tax liability divided by lifetime income:

$$
\mathrm{SMOOTH}=\frac{T_{S}-T_{P}}{N \cdot Y}
$$

\subsection{Data and Estimation}

We first discuss the construction of the marginal tax rate data. Then, we provide details of all non-tax data and parameters we use in the analysis.

\subsubsection{Marginal Tax Rates}

We construct a proxy for the marginal tax rate of a representative household that chooses between holding stocks inside or outside a pension plan. Importantly, this proxy should satisfy a number of 
criteria. First, it should be estimated consistently across years and countries so that it facilitates our empirical analysis. A convenient and robust method to ensure this is to calculate marginal tax rates for households at annual incomes for each multiple of GDP-per-capita, which is easy to compute from statutory tax tables. We denote with GDP $k$ the household taxable income equal to GDP per capita times a multiple $k$. Second, it should exclude very low income multiples as poor households are unlikely to own any financial assets, and because government-provided public pensions such as social security crowd out any desire of these households to save for retirement. As our base case, we assume that the representative household has an annual income of five times GDP per capita (GDP5). For example, the U.S. GDP per capita in 2009 is $\$ 46,000$ and thus the marginal tax rates for that year will be estimated in the base case for a household with an income of $\$ 230,000$. While the choice of this multiple is somewhat arbitrary, extensive robustness tests show that our results are not materially affected when we vary $k$ (see Section 5.2 ).

Dividends are generally taxed as ordinary income, even though many tax codes offer a dividendtax relief to reduce the effects of double taxation of corporate income 20 Capital gains taxation is markedly different from dividend taxation ${ }^{21}$ The statutory tax rate on long-term capital gains is usually lower than the statutory rate on short-term gains and it is often zero; in addition, in all countries capital gains tax can be postponed until the stock is sold. The value of deferral of capital gains has been subject to much debate. Miller (1977) refers to conventional folk wisdom that 10 years of tax deferral is almost as good as exemption from tax. Bailey (1969) calculates the value of deferral as $50 \%$ of the statutory rate, Protopapadakis (1983) finds estimates in the order of 25\%, and Chay, Choi, and Pontiff (2006) find it to be 55\%. Green and Hollifield (2003) model the advantage of deferral and find numerically that the effective tax rate on capital gains amounts to approximately $50-60 \%$ of the statutory rate. For the base case scenario, we therefore assume that the effective capital gains tax rate is $50 \%$ of the long-term statutory rate evaluated at the annual income five times GDP per capita. 22

\footnotetext{
${ }^{20}$ Dividend-tax relief was introduced in the following years: Canada 1949, Japan 1950, France 1965, United Kingdom 1973, Germany 1977, Sweden 1991, Finland 1993, and the United States 2003. See Appendix B for more details.

${ }^{21}$ The United States begins taxing capital gains on stocks in 1916, but elsewhere taxation of long-term capital gains is relatively recent: United Kingdom 1965, Sweden 1967, Canada 1972, and Finland 1986. In Germany, France, and Japan, long-term capital gains on stocks are effectively tax exempt throughout the time period we study.

${ }^{22}$ For robustness, we also varied the capital gains deferral parameter without materially affecting the results as
} 


\subsubsection{Non-Tax Data}

GDP per capita is taken from International Monetary Fund (2009), dividend yields are from Global Financial Data, and the Consumer Price Index (CPI) is from International Historical Statistics (Mitchell (2007)). Life-expectancy statistics are available from the Human Mortality Database ${ }^{23}$

Estimates of expected dividend yield and capital gains rate are intrinsically noisy. We make simple first-order approximations and pursue a number of robustness checks. In the base case, we assume that the expected dividend yield, $d$, is $4 \%$, and that the expected capital gains rate is $2 \%$ plus expected inflation measured as a three-year moving average of changes in CPI ${ }^{24}$ The assumptions on dividend yield (4\%) and capital gains yield (2\% plus inflation) imply that the expected real rate of return on stocks is approximately $6 \%$ before tax, which is within the range reported by Fama and French (2002) between 1951 and 2000: 4.74\% using the dividend growth model and $6.51 \%$ using the earnings growth model. The dividend yield parameter is similar to the pooled cross-section and time-series average dividend yield in our sample (3.6\%). There are two caveats to using this average as a dividend yield parameter. First, the time-series of cross-country average dividend yields exhibit a long-term downward-moving trend, from $5.3 \%$ in 1950 to $2.3 \%$ in 200625 Second, we treat payout policy as exogenous and do not allow for supply-side adjustments to changes in tax policy. ${ }^{26}$

As standard in asset pricing literature, we approximate the expected real dividend growth rate with the average real GDP-per-capita growth rate ${ }^{27}$ The real growth rate is also non-stationary.

Section 5.2 shows.

${ }^{23}$ University of California, Berkeley (USA), and Max Planck Institute for Demographic Research (Germany). Available at www.mortality.org or www.humanmortality.de.

${ }^{24}$ Arguably, inflation and long-term bond yields are mean reverting. However, as the time-series of actual long-term bond yields follow the three-year moving average inflation rate, a more sophisticated inflation-forecast model will not change any of the results.

${ }^{25}$ Substantially lower dividend yields in the United States and United Kingdom after 1982 can partially be explained by a dramatic increase in popularity of share repurchases following changes in regulations.

${ }^{26}$ Possible feedback mechanisms between payout policies and taxes are complex. Specifically, although higher income tax may lead firms to cut back their dividends and raise capital gains, the possible effect of higher capital gains tax is the opposite. Higher income tax may also reduce investments and thereby future dividends and capital gains. Empirically, very little is known. Many papers studied the effects of the dividend tax cut in 2003 (the Jobs and Growth Tax Relief Reconciliation Act of 2003). As this evidence is based on a single event, researchers debate whether the experiment is contaminated by other changes that take place around the time of the dividend tax cut (see Julio and Ikenberry (2004), Chetty and Saez (2005), and Brav, Graham, Harvey, and Michaely (2008)).

${ }^{27}$ Asset pricing papers that emanate from the consumption-based capital asset pricing model of Lucas (1978) measure aggregate consumption as GDP per capita, and therefore consumption growth as changes in GDP per capita. 
The geometric average real GDP growth rate in the pooled sample is $2.9 \%$, but the average decreases as we exclude the earlier data and measure it over recent years. Since 1990, the geometric average real GDP growth rate is only 1.4\%. In robustness tests in Section 5.2 , we replicate our results varying both the dividend yield and the growth rate. We also experiment with moving-average estimates of the two parameters.

The numerical value of the tax benefit to income smoothing depends on demographic parameters. In the base case, we assume that an individual begins contributing to a pension plan at the age of 25 and retires at the age of 6528 We assume that households use life-expectancy statistics to predict the number of years in retirement. For each country in our sample, we collect life-expectancy conditional on age 25 and compute the cross-country average of male and female life expectancy. Across countries, the time-series of average life expectancy begins at 70 years in 1950 and ends at 81 years in 2006. These numbers imply that the number of work years is $N=40$ and the number of retirement years is $M \in[6.4,16.4]$. The number of retirement years is an approximately linearly increasing function of time. Accordingly, the importance of saving for retirement increases over time 29

\subsection{Evolution on Personal Income Tax on Stocks}

In this section, we present and discuss the evolution of personal income tax. The sequence of plots contained in Figures $5 \mathrm{a} 5 \mathrm{~d}$ shows the evolution of marginal tax rates. In all plots, the solid line above is the top statutory rate on ordinary income, and the dashed line below is the top statutory rate on dividends. The numbers adjacent to the top statutory tax rate (solid line) are the top income tax brackets expressed as multiples of GDP per capita. Below the top statutory rates, we

Examples include Grossman and Shiller (1981) and Mehra and Prescott (1985). Traditional finance research estimate aggregate income growth from stock price indices, dividend series, and corporate earnings series. For example, Fama and French (2002) report that stock prices grow by $5.92 \%$ from 1951-2000, dividends 1.05\%, and corporate earnings $2.74 \%$. Presumably, all these measures of aggregate income are co-integrated. We use GDP per capita, which is most easily available for countries other than the United States.

${ }^{28}$ Retirement at 65 has long been the norm in the countries we study. It was chosen in the social security system of the United Kingdom in 1925 and in the United States in 1935.

${ }^{29}$ For simplicity, we ignore the change in life expectancy between the ages of 25 and 65 , i.e., we assume that a household that starts saving for retirement in 1950 uses the life expectancy statistical tables of 1950 to plan for retirement that begins forty years later in 1990. This assumption has no other consequence than shifting the numerical value of SMOOTH. See Footnote 19 above. 
plot our proxies for the marginal tax rate on dividends (diamonds) and capital gains (triangles) of the GDP5 household.

The top panel of Figure $5 \mathrm{a}$ shows the evolution of marginal tax rates in the United States. We assume that state tax is a constant $5 \%$. The top statutory rate on ordinary income equals the top statutory rate on dividends between 1950 and 2002. Since 2003, dividends are taxed at a lower rate. (This change in the tax code is represented by the dashed line.) Even though the top statutory income tax rate is exceedingly high at the beginning of the sample $(91.45-92.4 \%$ between 1950 and 1964), it is relevant to a few households. Over the same period, the top statutory income tax rate is activated only for households with a multiple 115-206 (for married couples filed jointly). The marginal tax rates on dividends and capital gains for the GDP5 household are, in fact, substantially lower, at 30-33\%. Over long time, two opposite forces affect the marginal tax rates. First, the top statutory income tax rate gradually and substantially declines to the level below $40 \%$ after TRA 1986. This tends to reduce marginal tax rates. Second, the multiple at which the top statutory rate is activated declines precipitously from 222 in 1950 to just $6-8$ over the past 20 years. The second effect, bracket creep, which increases marginal tax rates, dominates between 1965 and 1980. Thus, over that period the GDP5 household experienced substantial increase in its tax burden despite reduction in top tax rates. The Reagan reforms of 1982 and 1986 reverse the bracket creep which leads to the prevalence of the first effect. In addition, TRA 1986 introduces automatic inflation indexation which virtually removes the second effect. The capital gains tax rate (triangles) is approximately constant around $10 \%$.

The comparison of the evolution of tax rates between various countries in our sample provides the most direct justification for using a cross-country panel to address our research questions. The plots clearly demonstrate that there are substantial time-series and cross-sectional differences in tax rates that will allow us to use within-panel variation. For example, the treatment of dividend tax reliefs is very different across the countries. As another striking example, capital gains tax is absent in France, Germany, and Japan for the whole period and in other countries for extensive periods, with the United States being the only country that imposes capital gains tax throughout the whole period. 
Figure 5a: Marginal Tax Rates

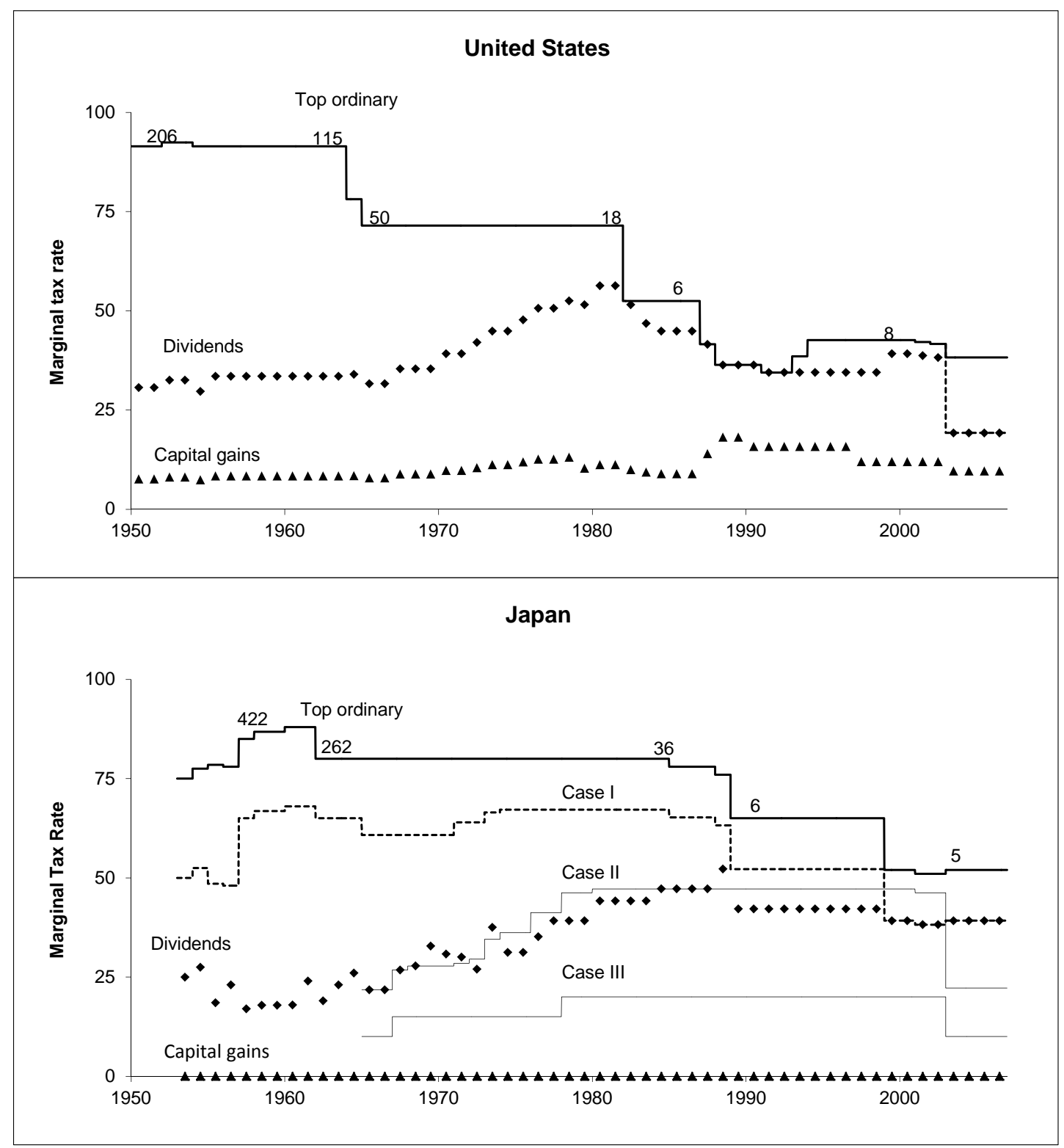

The figure shows the top statutory tax rate (solid line), the top statutory rate on dividends (dashed line), the marginal tax rate on dividends (diamonds) and long-term capital gains (triangles) of the GDP5 household. The numbers adjacent to the top statutory rate are top income brackets of representative years expressed in multiples of GDP per capita. In Japan, the marginal tax rate depends on the size of the dividend from each company. Cases I, II, and III refer to a large, an intermediate, and a small dividend, respectively. 
Figure 5b: Marginal Tax Rates

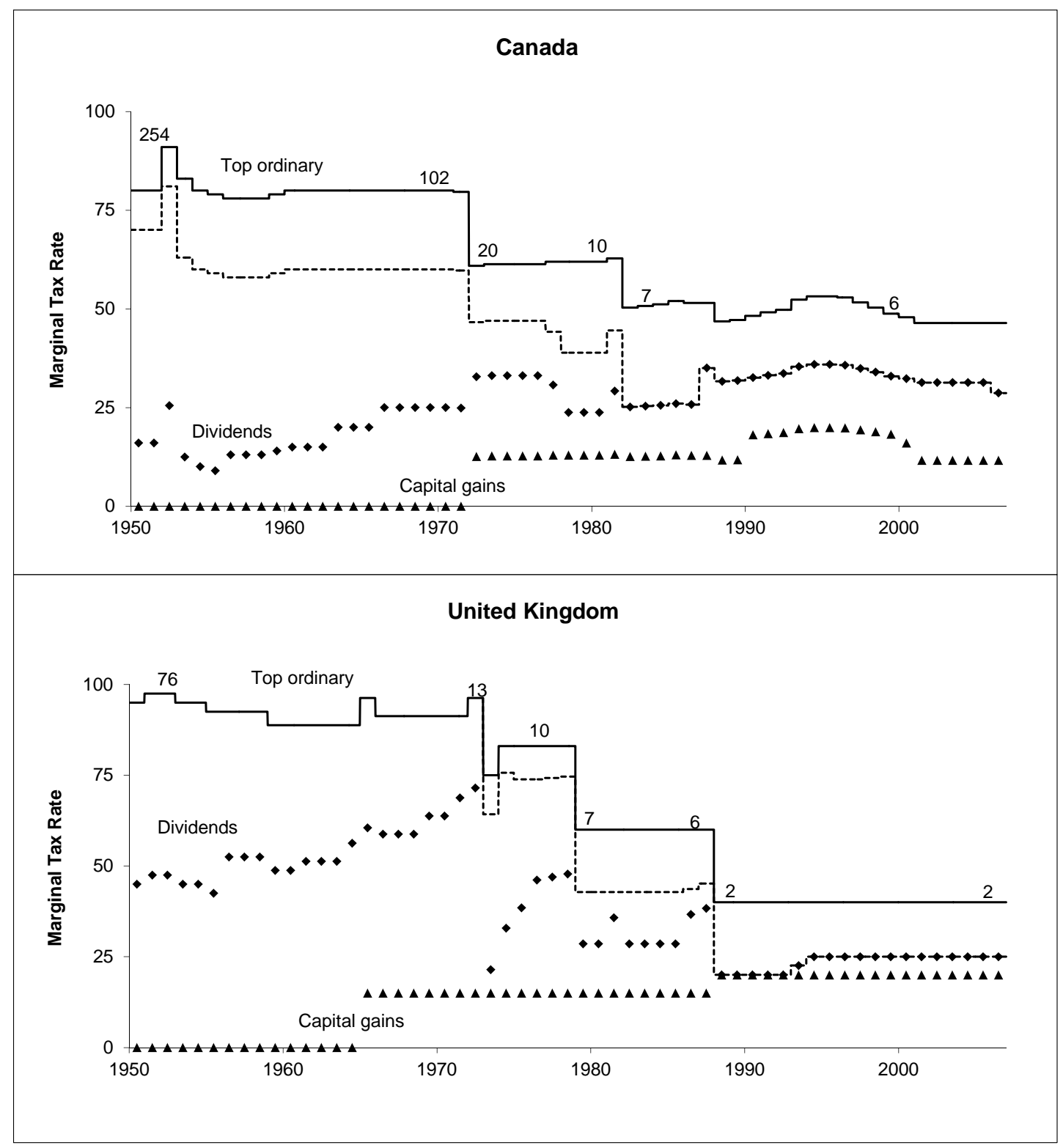

The figure shows the top statutory tax rate (solid line), the top statutory rate on dividends (dashed line), the marginal tax rate on dividends (diamonds) and long-term capital gains (triangles) of the representative GDP5 household. The numbers adjacent to the top statutory rate are top income brackets of representative years expressed in multiples of GDP per capita. 
Figure 5c: Marginal Tax Rates

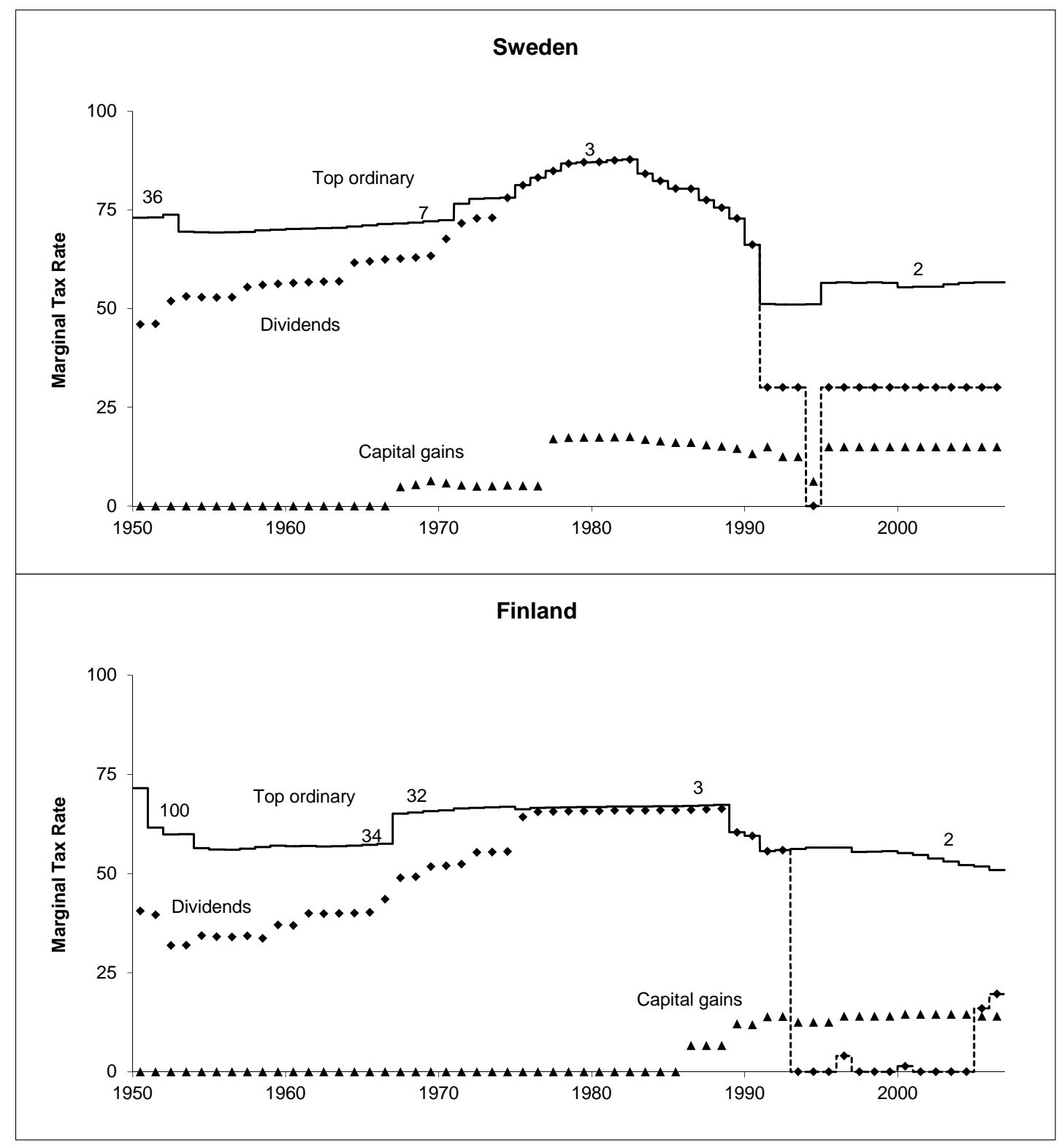

The figure shows the top statutory tax rate (solid line), the top statutory rate on dividends (dashed line), the marginal tax rate on dividends (diamonds) and long-term capital gains (triangles) of the representative GDP5 household. The numbers adjacent to the top statutory rate are top income brackets of representative years expressed in multiples of GDP per capita. 
Figure 5d: Marginal Tax Rates

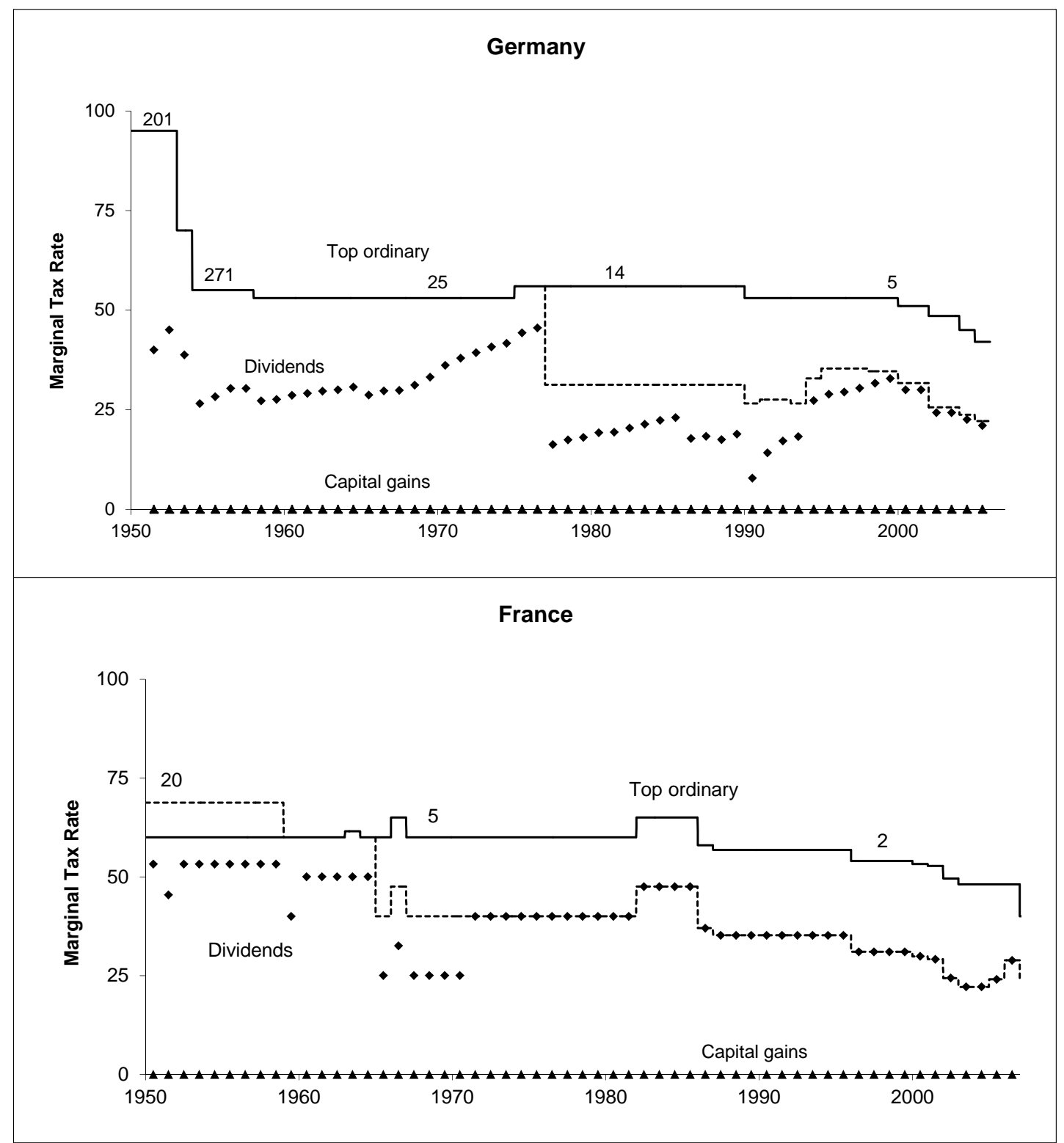

The figure shows the top statutory tax rate (solid line), the top statutory rate on dividends (dashed line), the marginal tax rate on dividends (diamonds) and long-term capital gains (triangles) of the representative GDP5 household. The numbers adjacent to the top statutory rate are top income tax brackets of representative years expressed in multiples of GDP per capita. 
At the same time, the evolution of tax systems share a number of common features. In the first decade after World War II, high top statutory rates on personal income are coupled with low marginal tax rates for the GDP5 household. In the subsequent decades, marginal tax rates drift upwards (bracket creep), and the GDP-per-capita multiple at the top statutory rate decreases from an average well above 100 in 1950 to around 10 in 1980. In the extreme cases of Sweden and Finland (Figure 5c), the marginal tax rates of the GDP5 household are equal to the top statutory rates in the 1970s and 1980s, and the top statutory rate applies to an income multiple of only two. The bracket creep, that ended with TRA 1986 in the United States, faced similar tax reforms in other countries: the United Kingdom 1988, Japan 1989, Sweden 1991, and Finland 1993. In all the countries, the marginal tax rates of the GDP5 household become similar to top statutory rates over the past 20 years but top statutory rates are much lower than in the past.

\subsection{Tax Benefits of Pensions}

In this section, we study the time-series and cross-country properties of the two empirical proxies of the tax benefits of pensions, GAP and SMOOTH. Figure 6a and 6b show the evolution of GAP5 in each of the eight sample countries. The sample average GAP5 is about $2 \%$, ranging from $1 \%$ in Germany to $2.8 \%$ in the United Kingdom. To illustrate the economic importance of GAP, consider the following simple example. If a household saves for retirement by placing $\$ 1$ in a savings account for 40 years at the pre-tax annual return of $6 \%$, then if GAP is equal to $2 \%$, the value of household's account at the end of 40 years is $\$ 155$ vs. $\$ 95$, or a gain of more than $60 \%$ by shifting from outside to inside pension account. The upshot is that for most sets of realistic parameters the GAP measure has a substantial impact on household's economic well-being.

The figure demonstrates substantial cross-country and time-series variation in the GAP measure. In the United States, United Kingdom, and Sweden, the path is hump shaped, with GAP5 peaking in the 1970s because of the increasing taxation of dividends (bracket creep) and capital gains (higher inflation effectively increases capital gains tax as taxation is levied on nominal changes in stock prices). For example, in the United Kingdom, GAP5 peaks at nearly 6\%, which implies that, under our assumptions, the expected real rate of return on stocks after tax is approximately 
Figure 6a: Benefit of Tax-Exempt Investment Income

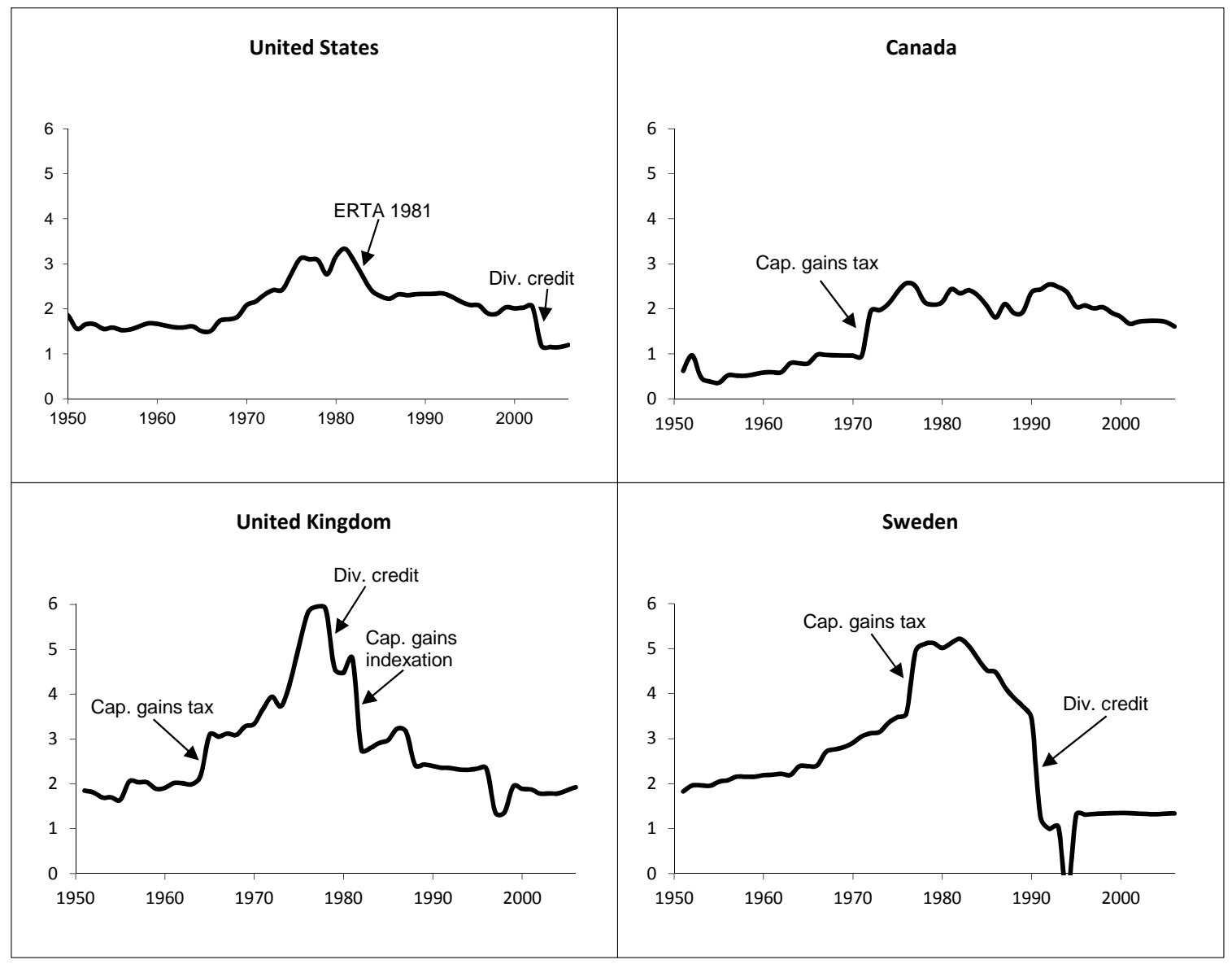

The figure shows the real rate of return difference between saving inside and outside a pension plan for a household with an income multiple of five times GDP per capita (GAP5). The numbers are expressed in percent. We assume that the expected dividend yield is $d=4 \%$, expected real growth is $g=2 \%$, and that expected inflation equals the three-year moving average. We also assume that the effective capital gains tax rate equals $50 \%$ of the long-term statutory rate. Jumps caused by important tax reforms are marked in the figure and explained in Appendix B 
Figure 6b: Benefit of Tax-Exempt Investment Income

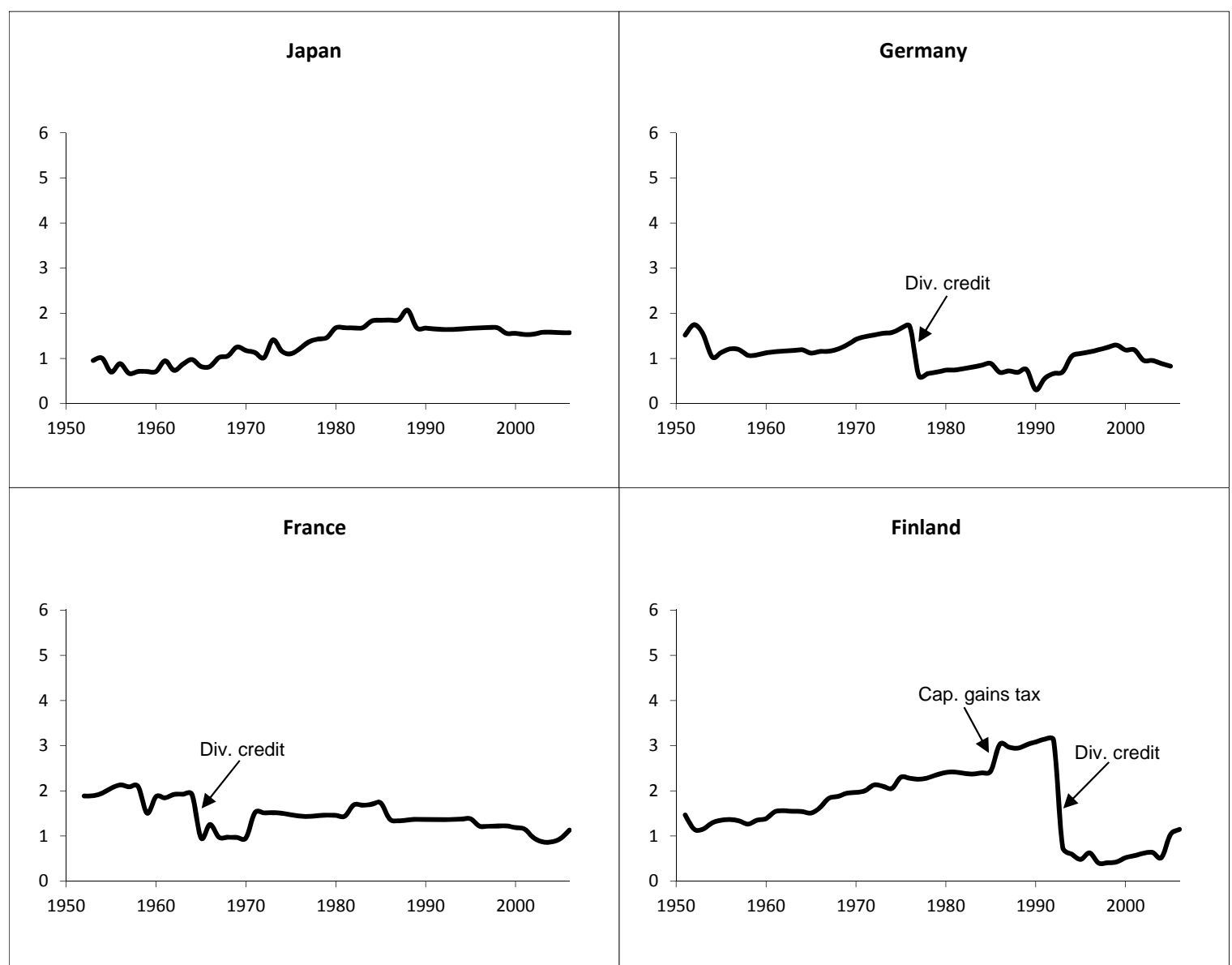

The figure shows the real rate of return difference between saving inside and outside a pension plan for a household with an income multiple of five times GDP per capita (GAP5). The numbers are expressed in percent. We assume that the expected dividend yield is $d=4 \%$, expected real growth is $g=2 \%$, and that expected inflation equals the three-year moving average. We also assume that the effective capital gains tax rate equals $50 \%$ of the long-term statutory rate. Jumps caused by important tax reforms are marked in the figure and explained in Appendix B 
zero. At the same time, in France, Germany, and Japan, the response to the inflation shock of the 1970s is minimal, because the effective dividend taxation is low (the dividend tax credit protects against bracket creep) and capital gains are exempt from taxation. The importance of dividend tax credits can be seen in the plots of the United States, United Kingdom Sweden, Germany, France, and Finland where GAP5 decreases after tax reforms that relieve shareholders of double dividend taxation. The effects of capital gains taxation are visible in Canada, United Kingdom, Sweden, and Finland, where GAP5 increases after the introduction of capital gains taxation, as well as in the United Kingdom 1982, where GAP5 drops after capital gains are protected against inflation through indexation.

Figure 7 shows the evolution of the tax benefit of income smoothing, proxied by SMOOTH5. SMOOTH5 is almost always positive because personal tax tables are progressive, with the average annual reduction in the tax bill in the pooled sample of $2.6 \% 30$ In the United States and the United Kingdom, the time-series of SMOOTH5 display the same hump-shaped path as GAP5, which peaks in the 1970s when tax progressivity is high. Effectively, the GDP5 household moves upwards into the more progressive part of the tax table because of the bracket creep. All the SMOOTH5 time-series exhibit an upward-sloping trend, which is explained by increasing life expectancy on the smoothing benefit. Precipitous drops in the late 1980s - early 1990s are the result of TRA 1986 in the United States (marked on the plot) and similar tax reforms in other countries. The correlation between GAP5 and SMOOTH5 in the pooled sample is relatively small at 0.17 implying that these two proxies reflect different economic channels.

\section{Tax Benefits of Pensions and the Evolution of Ownership}

In this section we investigate to what extent government policies may have shaped the structure of ownership of financial assets. Our main conjecture is that households shifted their ownership away from direct holdings as these became more tax disadvantaged and that the speed of this shift has been related, both cross-sectionally and in time-series, by the strength of the tax differential

\footnotetext{
${ }^{30}$ Rydqvist, Schwartz, and Spizman (2010) quantify the magnitude of the tax benefit of income smoothing for the Unites States in much more detail.
} 
Figure 7: Tax Benefit of Income Smoothing

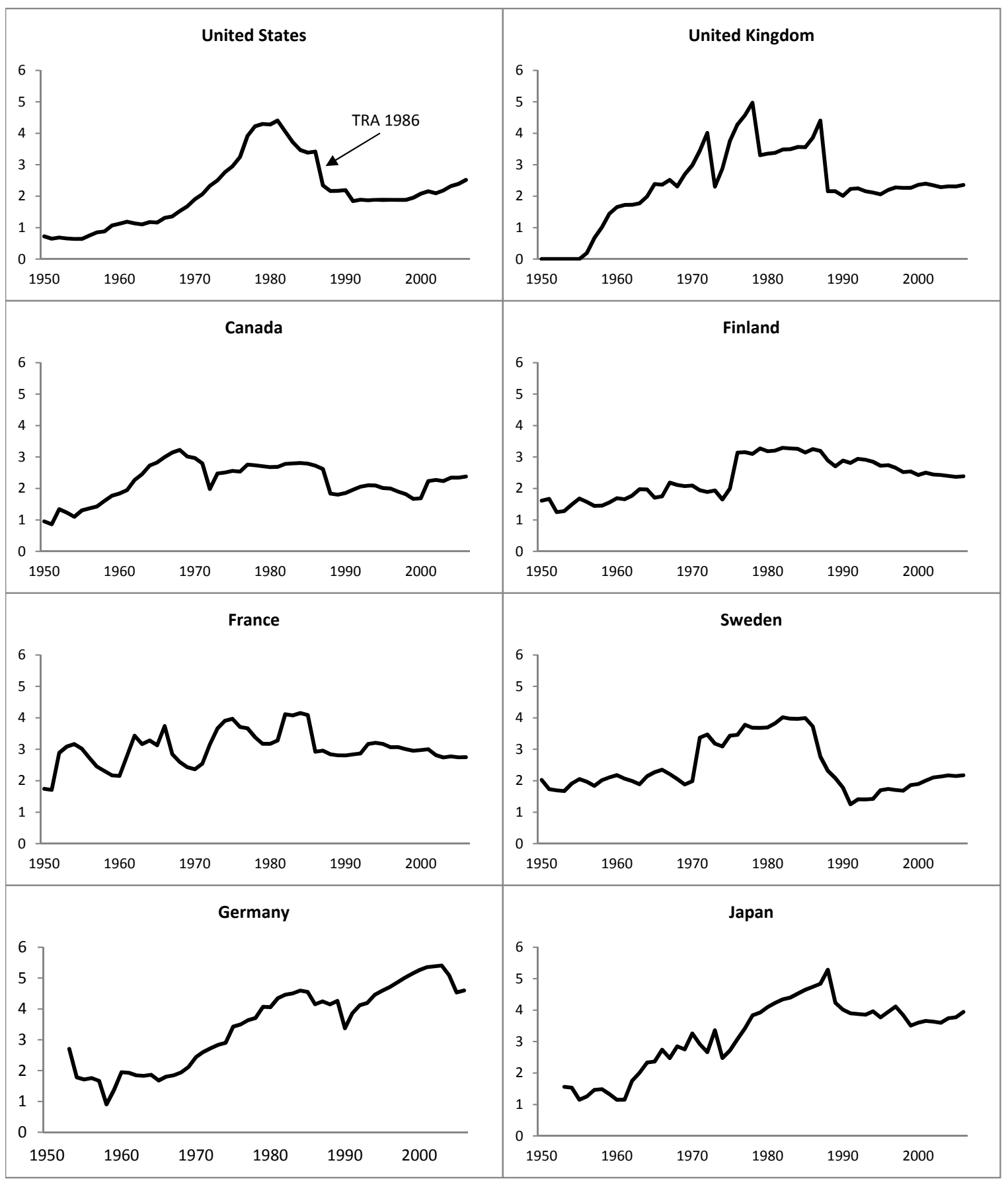

The figure shows the tax benefit to income smoothing for a household with an income multiple of five times GDP per capita (SMOOTH5). The numbers are expressed in percent. The calculations are based on statutory tax tables, retirement age 65 , average life expectancy conditional on age 25 , and zero interest rate. 
of direct vs. indirect holdings. The goal is thus to explore whether systematic evidence fits the essence of the example of the U.S. mutual and pension fund industries, presented in Section 2.1.

\subsection{Panel Evidence}

To start with, we need to estimate households' aggregate response to the tax incentives to save inside a pension plan. The dependent variable is the change in the fraction of household ownership, $\Delta y$, and the independent variables are GAP5 and SMOOTH5. We estimate the following pooled cross-section and time-series regression model:

$$
\Delta y_{i t}=a+b \cdot \operatorname{GAP} 5_{i t}+c \cdot \operatorname{SMOOTH} 5_{i t}+e_{i t} .
$$

Our conjecture implies that the GAP5 and SMOOTH5 slope coefficients, $b$ and $c$, are negative. It is important to emphasize that the incentives to save inside a pension plan are very slowmoving variables. Any delayed response is likely to be highly correlated with the current values of the incentive variables. Therefore, in the base case regression model, we run contemporaneous regressions and do not include lagged independent variables. If there is an underlying time trend in the fraction of household ownership such as the effect of increased life expectancy, then the time trend is captured by the regression intercept. In our base case model, we also ignore that the fraction of household ownership is bounded between zero and one and therefore the changes can depend on the level of the dependent variable. Finally, we do not control for the possible country-specific time trend 31 A number of variations in specification are addressed in our robustness tests.

As the time series of ownership are incomplete for the United Kingdom, Sweden, and Finland, particularly in the beginning of the sample period, missing values are replaced through a procedure of random imputation. Specifically, we interpolate the missing value as the average annual change in household ownership between two observations and add random noise:

$$
\Delta y_{i t}=\frac{y_{i t}-y_{i t-n}}{n}+\epsilon_{i t}
$$

\footnotetext{
${ }^{31}$ When we allow the underlying time trend to vary across countries (i.e., country-fixed effects), only the coefficient of the dummy variable for Canada is statistically different from zero.
} 
where $n>1$ and the noise term is normally distributed with zero mean and standard deviation estimated from the portion of the data without missing data. Intuitively, the average change in household ownership between two data points is our best guess for the missing value. The noise term protects against underestimating the standard errors of the regressions ${ }^{32}$ We use random imputation to fill in the missing values for 91 of 396 observations, or $23 \%$ of the total sample. For the individual countries, we impute $48 \%$ of the observations from Finland, $62 \%$ from Sweden, and $72 \%$ from the United Kingdom. Since the imputed observations constitute a relatively large portion of the sample, we simulate 100 paths and report average regression statistics. In the robustness section, we compare the regression results of random imputation with other methods of dealing with missing data. The estimation procedure corrects for first-order autocorrelation and heteroscedasticity following the procedure of Parks (1967) ${ }^{33}$

Table 2 reports the results of estimating Equation (9). As the empirical model is specified in first differences, we expect low levels of $R^{2}$ coefficients. Specification (1) reports only the average annual change in household ownership across the eight countries. The average decline in the fraction of household ownership is $0.75 \%$ per year. Specifications (2)-(4) include the tax proxy variables. The coefficient of GAP5 is significantly different from zero, while the coefficient of SMOOTH5 is not. These results contrast with the mainstream view that income smoothing is important (e.g. see Ippolito (1986) for a theoretical discussion).

Importantly, once we include the tax variables, the intercept term is not statistically different from zero, which implies that the entire underlying time trend is due to the effect of taxation. Economically, the magnitude of the regression coefficient of GAP5 means that a three percentage point difference between saving inside and outside a pension plan results in an annual reduction of the fraction of household ownership by one percentage point. When we break down GAP5 into its components (Specifications (3) and (4)), we see that the dividend term and the marginal tax rates on dividends have explanatory power, but not the capital gains term, the marginal tax rate

\footnotetext{
${ }^{32}$ Standard software packages such as SAS, Stata, and SPSS include missing values procedures that explicitly take the uncertainty of the imputed value into account. For an introduction to missing data analysis, see Howell (2008). We thank David Howell and Subal Kumbhakar for commenting on the missing data procedure.

${ }^{33}$ Since the dependent variable is defined as the first difference, the residual autocorrelation is close to zero. We nevertheless correct for the remaining autocorrelation using the same autocorrelation coefficient for all the countries.
} 
Table 2: Pooled Regressions

\begin{tabular}{|c|c|c|c|c|}
\hline & $(1)$ & $(2)$ & $(3)$ & $(4)$ \\
\hline Constant & $\begin{array}{c}-0.75 \\
(-8.5)^{* * *}\end{array}$ & $\begin{array}{l}-0.20 \\
(-0.8)\end{array}$ & $\begin{array}{l}-0.14 \\
(-0.5)\end{array}$ & $\begin{array}{l}0.00 \\
(0.0)\end{array}$ \\
\hline GAP5 & & $\begin{array}{c}-31.1 \\
(-3.6)^{* * *}\end{array}$ & & \\
\hline Dividend term & & & $\begin{array}{c}-39.4 \\
(-2.6)^{* * *}\end{array}$ & \\
\hline Capital gains term & & & $\begin{array}{l}-21.0 \\
(-1.2)\end{array}$ & \\
\hline Dividend tax rate & & & & $\begin{array}{c}-1.7 \\
(-3.0)^{* * *}\end{array}$ \\
\hline Capital gains tax rate & & & & $\begin{array}{l}-1.0 \\
(-0.8)\end{array}$ \\
\hline Inflation rate & & & & $\begin{array}{l}-1.6 \\
(-0.6)\end{array}$ \\
\hline SMOOTH5 & & $\begin{array}{c}0.8 \\
(0.1)\end{array}$ & $\begin{array}{c}1.8 \\
(0.2)\end{array}$ & $\begin{array}{c}0.5 \\
(0.1)\end{array}$ \\
\hline $\mathrm{R}^{2}$ & 0.000 & 0.034 & 0.035 & 0.032 \\
\hline \#Observations & 396 & 396 & 396 & 396 \\
\hline
\end{tabular}

The table reports the results of regressing the households' annual percentage ownership change on proxy variables for the tax benefits of saving inside a pension plan defined by equations (5) and (8). The proxy variables are functions of marginal tax rates that are evaluated at the income five times GDP per capita. The regressions are estimated with generalized least squares. Missing data are replaced through random imputation as described in the text. t-statistics are reported in parentheses below the coefficients. Asterisk ${ }^{*},{ }^{* *}$, and ${ }^{* * *}$ denote significance level $10 \%, 5 \%$, and $1 \%$ or better, respectively, against the null hypothesis that the coefficient is zero. 
on capital gains, or inflation. These results suggest that dividend taxation matters for long-term household behavior.

Table 3: Decade-by-Decade Regressions

\begin{tabular}{lcccccc}
\hline \hline & $1950-59$ & $1960-69$ & $1970-79$ & $1980-89$ & $1990-99$ & $2000-10$ \\
\hline Constant & -0.66 & 0.32 & 0.15 & 0.58 & -2.2 & 0.84 \\
& $(-0.7)$ & $(0.5)$ & $(0.2)$ & $(0.7)$ & $(-2.6)^{* * *}$ & $(1.0)$ \\
GAP5 & 37.1 & -47.3 & -23.7 & -43.8 & 19.3 & -64.8 \\
SMOOTH5 & $(0.7)$ & $(-2.0)^{* *}$ & $(-1.6)^{*}$ & $(-3.2)^{* * *}$ & $(0.7)$ & $(-1.6)$ \\
$\mathrm{R}^{2}$ & -50.5 & -6.3 & -16.8 & -12.5 & 36.7 & -9.5 \\
\#Observations & $(-1.3)$ & $(-0.3)$ & $(-0.6)$ & $(-0.7)$ & $(2.4)^{* *}$ & $(-0.5)$ \\
& 0.047 & 0.133 & 0.090 & 0.111 & 0.008 & 0.087 \\
\end{tabular}

The table reports the regression results decade by decade. The dependent variable is the households' annual percentage ownership change and the independent variables are proxy variables for the tax benefits of saving inside a retirement account. The proxy variables are functions of marginal tax rates that are evaluated at the income five times GDP per capita. The regressions are estimated as in Table 2 t-statistics are reported in parentheses below the coefficients. Asterisk ${ }^{*},{ }^{* *}$, and ${ }^{* * *}$ denote significance level $10 \%, 5 \%$, and $1 \%$ or better, respectively, against the null hypothesis that the coefficient is zero.

Once the economic significance of tax variables is established, it is important to explore the timeseries and cross-country determinants of their impact. Table 3 reports the results of estimating the regression model (9) decade by decade. For brevity, we report only the results using GAP5 and SMOOTH5 as regressors. The coefficient of GAP5 is statistically different from zero in the three regressions covering the 1960s, 1970s, and 1980s, with a similar economic magnitude to the full panel estimate. Statistical significance varies, it is marginal in the 1960s and the 1970s and strong in the 1980s. These results demonstrate that the explanatory power of the regression model (9) is due to the cross-sectional variation in marginal tax rates during the high-inflation periods, suggesting that bracket creep is a driving force behind household decisions.

The SMOOTH5 coefficients are insignificant in each decade, confirming the results of Table 2. A likely explanation of the statistical significance of the intercept coefficient in the 1990s is that the decline in household ownership is driven by an increase in cross-border ownership once the capital controls were widely abolished around that time. Although our data do not allow us to explore this conjecture further, it is highly likely that financial institutions are behind much of this foreign 
ownership. For example, Ferreira and Matos (2008) estimate that $60 \%$ of the U.S. stocks owned by the foreigners (or $6 \%$ of the total U.S. stock market value) is owned by foreign financial institutions.

Table 4: Country-by-Country Regressions

\begin{tabular}{lccccccccc}
\hline \hline & Sweden & $\begin{array}{c}\text { United } \\
\text { Kingdom }\end{array}$ & $\begin{array}{c}\text { United } \\
\text { States }\end{array}$ & Germany & Finland & Japan & France & Canada \\
\hline Constant & 0.33 & -0.74 & -0.09 & 1.16 & 0.87 & -1.5 & 2.6 & -1.71 \\
& $(0.5)$ & $(-1.0)$ & $(-0.3)$ & $(0.8)$ & $(0.7)$ & $(-2.3)^{* *}$ & $(0.9)$ & $(-0.9)$ \\
GAP5 & -50.8 & -41.6 & -16.4 & -134.5 & -5.1 & 143.7 & 32.8 & -11.2 \\
& $(-2.0)^{* *}$ & $(-1.4)$ & $(-0.4)$ & $(-1.5)$ & $(-0.2)$ & $(1.1)$ & $(0.1)$ & $(-0.2)$ \\
SMOOTH5 & 1.9 & 32.7 & -22.8 & -9.5 & -69.7 & -33.0 & -121.8 & 65.7 \\
$\mathrm{R}^{2}$ & $(0.1)$ & $(0.8)$ & $(-1.0)$ & $(-0.4)$ & $(-1.4)$ & $(-0.7)$ & $(-0.8)$ & $(1.0)$ \\
\#Observations & 0.462 & 0.092 & 0.045 & 0.056 & 0.021 & 0.055 & 0.027 & 0.052 \\
& 56 & 47 & 65 & 55 & 46 & 54 & 28 & 45 \\
\hline
\end{tabular}

The table reports the regression results by country. The dependent variable is the households' annual percentage ownership change and the independent variables are proxy variables for the tax benefits of saving inside a retirement account. The proxy variables are functions of marginal tax rates that are evaluated at the income five times GDP per capita. The regressions are estimated as in Table 2, t-statistics are reported in parentheses below the coefficients. Asterisk ${ }^{*},{ }^{* *}$, and ${ }^{* * *}$ denote significance level $10 \%, 5 \%$, and $1 \%$ or better, respectively, against the null hypothesis that the coefficient is zero.

When we estimate the regression within each country, the GAP5 variable has explanatory power only in Sweden, where high effective taxation of dividends and capital gains in the 1970s and 1980s coincides with the migration of shares from the household sector to financial institutions and corporations. There is no statistically significant relation in the United States, because the rate of change in the fraction of household ownership is fast and steady both before and after TRA 1986, when effective taxation of stock income decreases significantly.

\subsection{Robustness tests}

In constructing benchmark proxies for tax rate variables, SMOOTH and GAP, we inevitably have to make a number of ad hoc assumptions. In this section, we submit our empirical results to a number of stress tests to explore their robustness. The overall conclusion is that our results are robust to a number of important variations in parameter assumptions as well as in econometric methodology. 


\subsubsection{Parameters}

We start by re-considering the main economic result from the panel regression (9) that the GAP5 variable predicts changes in the fraction of household ownership. The construction of GAP5 depends on several parameter choices. Specifically, we assumed a particular GDP income multiple of five, we assumed the capital gains tax deferral parameter value of 0.50 , the constant dividend yield of $4 \%$, and the dividend growth rate of $2 \%$. Figure 8 examines how the regression coefficient of GAP changes when we vary any of these four parameters. In each plot, the regression coefficient of

Figure 8: Robustness to Parameter Choices

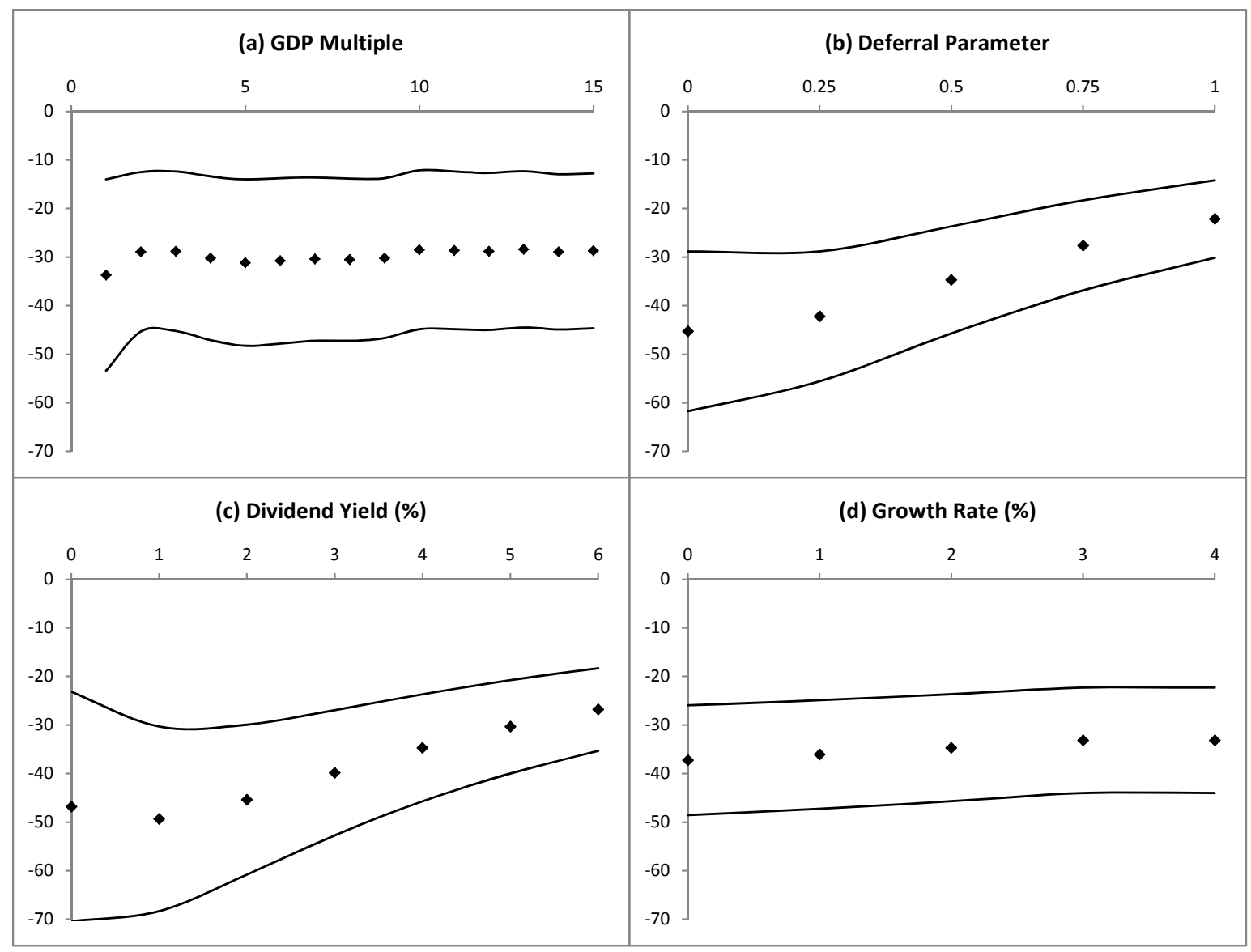

The four figures report the estimated regression coefficient of GAP5 (diamonds) and a 95\% confidence interval (solid lines) as we vary the income multiple (a), capital gains tax deferral parameter (b), the dividend yield (c), and the dividend growth rate (d). The regressions are estimated as in Table 2

GAP is marked by a diamond with a $95 \%$ confidence interval represented by the solid lines above 
and below. We vary the income multiple from GDP1 to GDP15 (Panel (a)), the capital gains tax deferral parameter from $0 \%$ (no capital gains tax) to $100 \%$ (full statutory rate) (Panel (b)), the dividend yield from $0 \%$ to $6 \%$ (Panel (c)), and the dividend growth rate from $0 \%$ to $4 \%$ (Panel (d)).

Across all four comparative statics experiments, the regression coefficient is almost invariant to parameter changes and the upper boundary of the confidence interval is well below zero. In these experiments only one variable varies at a time. However, experiments where we vary more than one parameter simultaneously, e.g. the dividend yield and the dividend growth rate, do not have much impact on the GAP5 regression coefficient either. Hence, we conclude that the regression results are robust to the choice of specific parameters. While not reported in the plots, the regression coefficients of SMOOTH remain statistically insignificant across the various experiments ${ }^{34}$

Table 5: Time-Varying Parameters

\begin{tabular}{|c|c|c|c|c|}
\hline & $\begin{array}{l}\text { Constant } \\
\text { parameters } \\
(1)\end{array}$ & $\begin{array}{l}\text { Moving dividend \& } \\
\text { constant growth } \\
(2)\end{array}$ & $\begin{array}{l}\text { Constant dividend \& } \\
\text { moving growth } \\
(3)\end{array}$ & $\begin{array}{c}\text { Moving } \\
\text { parameters } \\
(4)\end{array}$ \\
\hline Constant & $\begin{array}{l}-0.20 \\
(-0.8)\end{array}$ & $\begin{array}{l}-0.23 \\
(-0.9)\end{array}$ & $\begin{array}{l}-0.25 \\
(-1.0)\end{array}$ & $\begin{array}{l}-0.26 \\
(-1.0)\end{array}$ \\
\hline GAP5 & $\begin{array}{c}-31.1 \\
(-3.6)^{* * *}\end{array}$ & $\begin{array}{c}-29.7 \\
(-3.9)^{* * *}\end{array}$ & $\begin{array}{c}-26.6 \\
(-3.2)^{* * *}\end{array}$ & $\begin{array}{c}-26.2 \\
(-3.5)^{* * *}\end{array}$ \\
\hline SMOOTH5 & $\begin{array}{c}0.8 \\
(0.1)\end{array}$ & $\begin{array}{c}-0.7 \\
(-0.1)\end{array}$ & $\begin{array}{c}-0.6 \\
(-0.1)\end{array}$ & $\begin{array}{c}-1.7 \\
(-0.2)\end{array}$ \\
\hline $\mathrm{R}^{2}$ & 0.034 & 0.042 & 0.039 & 0.038 \\
\hline \#Observations & 396 & 396 & 396 & 396 \\
\hline
\end{tabular}

The table reports the regression results with time-varying dividend yield and income growth. Specification (1) is our base case with dividend yield $d=4 \%$, real income growth $g=2 \%$, and three-year moving average inflation. The other three specifications measure either dividend yield or nominal income growth as three-year moving averages. For dividends, we create one aggregate dividend yield time-series from an equally weighted average across all countries and compute the three-year moving average dividend yield. For income growth, we average nominal GDP-per-capita time-series across countries and compute the three-year moving average nominal GDP-per-capita growth. The dependent variable is the households' annual percentage ownership change and the independent variables are proxy variables for the tax benefits of saving inside a retirement account. The proxy variables are functions of marginal tax rates that are evaluated at the income five times GDP per capita. The regressions are estimated as in Table 2 t-statistics are reported in parentheses below the coefficients. Asterisk ${ }^{*},{ }^{* *}$, and ${ }^{* * *}$ denote significance level $10 \%, 5 \%$, and $1 \%$ or better, respectively, against the null hypothesis that the coefficient is zero.

In our benchmark case, we assume that dividend yield and income growth are constants. This is a simplification as both the actual time-series appear to be non-stationary over the time period

\footnotetext{
${ }^{34}$ The unreported results on GAP and SMOOTH are available from the authors upon request.
} 
we study. Both dividend yields and real growth rates decrease over time. In Table 5, we examine the robustness of our regression results to relaxing the assumption of constant parameters. Specification (1) is our base case. The other three specifications vary either the dividend yield, the growth rate, or both as three-year moving averages. We see across the columns in the table that the regression results are similar and not dependent on our choice of constant or time-varying parameters. The reported results are based on aggregating dividend yield and GDP-per-capita time series across countries and use the same parameter for all countries at each point of time. The results are similar when we allow the dividend yield and GDP-per-capita time-series to be country specific.

\subsubsection{Limited Dependent Variable}

The benchmark panel regression model we employ is linear. In our case, it has an uncomfortable feature that it would predict that, after many years, the fraction of household ownership turns negative if the coefficient is below zero. A more realistic model would take into account that the effect of taxation diminishes as the level of household ownership decreases, such that the predicted level of household ownership converges to zero over long time. This limitation of the linear model is addressed by the following regression model, which interacts the lagged level of household ownership with the tax variables:

$$
\Delta y_{i t}=y_{i t-1}^{\gamma}\left(a+b \cdot \operatorname{GAP} 5_{i t}+c \cdot \mathrm{SMOOTH}_{i t}+e_{i t}\right)
$$

If the power coefficient equals one, $\gamma=1$, the tax variables have full effect when the lagged level of household ownership is $y_{i t-1}=1$, half effect when $y_{i t-1}=0.5$, and no effect when $y_{i t-1}=0$. If we reduce the power coefficient to $\gamma=0.5$, the tax variables have $70.7 \%$ effect when $y_{i t-1}=0.5$. The extreme version of the non-linear regression model (11) is when the power coefficient is $\gamma=0$, which brings us back to the benchmark linear regression model (9). A small power coefficient $\gamma>0$ implies that the regression model is almost linear at high and intermediate levels of household ownership, and highly non-linear when household ownership approaches zero.

Table (6) reports the results of the non-linear model estimation. In the first column we show 
Table 6: Non-Linear Regression Model

\begin{tabular}{|c|c|c|c|c|c|c|}
\hline & \multirow[b]{2}{*}{ Max likelihood } & \multicolumn{5}{|c|}{ Least squares } \\
\hline & & $\gamma=0$ & $\gamma=0.25$ & $\gamma=0.50$ & $\gamma=0.75$ & $\gamma=1.00$ \\
\hline Constant & $\begin{array}{l}-0.15 \\
(-0.5)\end{array}$ & $\begin{array}{l}-0.20 \\
(-0.8)\end{array}$ & $\begin{array}{l}-0.13 \\
(-0.9)\end{array}$ & $\begin{array}{l}-0.19 \\
(-0.8)\end{array}$ & $\begin{array}{l}-0.30 \\
(-1.4)\end{array}$ & $\begin{array}{l}-0.41 \\
(-2.1)^{* *}\end{array}$ \\
\hline$y_{t-1}^{\gamma}$ GAP5 & $\begin{array}{c}-31.2 \\
(-3.0)^{* * *}\end{array}$ & $\begin{array}{c}-31.1 \\
(-3.6)^{* * *}\end{array}$ & $\begin{array}{c}-36.4 \\
(-3.3)^{* * *}\end{array}$ & $\begin{array}{c}-35.9 \\
(-2.7)^{* * *}\end{array}$ & $\begin{array}{c}-34.1 \\
(-2.1)^{* *}\end{array}$ & $\begin{array}{c}-31.8 \\
(-1.6)^{*}\end{array}$ \\
\hline$y_{t-1}^{\gamma} \mathrm{SMOOTH} 5$ & $\begin{array}{c}-3.7 \\
(-0.3)\end{array}$ & $\begin{array}{c}0.8 \\
(0.1)\end{array}$ & $\begin{array}{l}-4.9 \\
(-0.4)\end{array}$ & $\begin{array}{l}-8.8 \\
(-0.6)\end{array}$ & $\begin{array}{c}-9.5 \\
(-0.5)\end{array}$ & $\begin{array}{l}-8.5 \\
(-0.1)\end{array}$ \\
\hline$\gamma$ & $\begin{array}{c}0.053 \\
(0.2)\end{array}$ & & & & & \\
\hline $\mathrm{R}^{2}$ & & 0.034 & 0.032 & 0.026 & 0.020 & 0.014 \\
\hline \#Observations & 396 & 396 & 396 & 396 & 396 & 396 \\
\hline
\end{tabular}

The table reports the regression results by country. The dependent variable is the households' annual percentage ownership change and the independent variables are proxy variables for the tax benefits of saving inside a retirement account. The proxy variables are functions of marginal tax rates that are evaluated at the income five times GDP per capita. The regressions are estimated as in Table 2 t-statistics are reported in parentheses below the coefficients. Asterisk ${ }^{*},{ }^{* *}$, and ${ }^{* * *}$ denote significance level $10 \%, 5 \%$, and $1 \%$ or better, respectively, against the null hypothesis that the coefficient is zero.

the maximum likelihood results, and in other columns the least squares results when the value of the power coefficient is superimposed. The second column $(\gamma=0)$ is the benchmark case. The maximum likelihood estimate is $\gamma=0.053$ with a t-statistic of 0.2 . These estimates mean that the linear regression model $(9)$ describes the data well as long as the level of household ownership is not close to zero. When we superimpose and raise the power coefficient $\gamma$, the explanatory power of the regression model decreases. A possible explanation why the lagged level of household ownership does not raise the overall explanatory power is that household ownership continues to decrease rapidly in the 1990s when foreign investors enter stock markets. Therefore, for spurious reasons, we do not see the decreasing effect of the tax variables as household ownership approaches zero.

\subsubsection{Missing Data}

The final Table 7 investigates the effect of how we deal with missing data. The base case results using random imputation are compared with the methods of multiple imputation and listwise deletion. Multiple imputation means that the regression coefficients from the complete portion of 
Table 7: Data Selection Model

\begin{tabular}{lccc}
\hline \hline & $\begin{array}{c}\text { Random imputation } \\
(1)\end{array}$ & $\begin{array}{c}\text { Multiple imputation } \\
(2)\end{array}$ & $\begin{array}{c}\text { Listwise deletion } \\
(3)\end{array}$ \\
\hline Constant & -0.20 & -0.18 & -0.20 \\
& $(-0.8)$ & $(-0.6)$ & $(-0.7)$ \\
GAP5 & -31.1 & -34.3 & $(-29.1)^{* *}$ \\
& $(-3.6)^{* * *}$ & $(-2.5)^{* * *}$ & 0.6 \\
SMOOTH5 & 0.8 & -0.2 & $(0.1)$ \\
$\mathrm{R}^{2}$ & $(0.1)$ & $(-0.0)$ & 0.018 \\
\#Observations & 0.034 & & 305 \\
\hline
\end{tabular}

The table reports the regression results under three different methods to handle missing values. Random imputation is our base case where we interpolate missing values and add white noise. Multiple imputation uses the regression parameters from the complete portion of the sample to impute the missing values. Listwise deletion uses only the complete portion of the data. The dependent variable is the households' annual percentage ownership change and the independent variables are proxy variables for the tax benefits of saving inside a retirement account. The proxy variables are functions of marginal tax rates that are evaluated at the income five times GDP per capita. The regressions are estimated as in Table 2. t-statistics are reported in parentheses below the coefficients. Asterisk *, **, and ${ }^{* * *}$ denote significance level $10 \%, 5 \%$, and $1 \%$ or better, respectively, against the null hypothesis that the coefficient is zero.

the data are used to fill in the missing values. The explanatory power of this data selection model is less than that of our base case because the information embedded in the scattered ownership data points from the early years in Finland, Sweden, and the United Kingdom is not used. Therefore, multiple imputation is not better than listwise deletion, which simply deletes the missing data. However, it is reassuring that our main regression results are also robust to the most conservative treatment of missing data.

\section{Conclusions}

In this paper, we have provided evidence that government policies enacted generations ago may have unintended long-term consequences. The response to the higher effective income taxation, implemented in the developed world in search of higher tax revenues since World War II, has been the precipitous decline in taxable direct household ownership transferred into various tax-deferred plans. This behavior partially reversed higher tax revenue goals and was an impulse for the development of the financial intermediary industry as we know it today. Our results bear significantly on 
several avenues of academic research (income taxation, corporate governance, financial institutions, asset pricing, to name a few) and public policy debates.

Our results and conjectures need to be seen in perspective to the tidal waive of influential academic research that argued that need for diversification and lowering transaction costs can explain stylized facts associated with financial institutions and asset ownership. Future research to compare and reconcile these arguments is certainly imperative, as the scope of our work has not allowed us to study in any meaningful way a number of alternative explanations. As an example, in a sequence of works, Allen and Gale (1994), Allen and Santomero (1998), and Allen and Gale (2000) argue that professional asset managers can use complex and sophisticated financial instruments to improve risk sharing beyond that of simple diversification and that risk sharing may be a leading force in observed changes in institutional and ownership structures. A problem for arguments based on risk sharing is to explain why mutual funds that specialize in risk sharing are small before they become part of the retirement system. Another challenge is to explain why the stock ownership structures of high-tax countries and low-tax countries follow different paths during the high-inflation period of the 1960s-80s. But a more fundamental empirical analysis of this as well as other conjectures is still to be attempted. 


\section{References}

Airaksinen, T., and T. Kallinen, 1987, Yhteisoomistus ja ristiinomistus suomalaisissa suuryrityksissa, working paper, Research Institute of the Finnish Economy.

Allen, Franklin, and Douglas Gale, 1994, Financial Innovation and Risk Sharing. (MIT Press, Cambridge, Massachusetts).

Allen, Franklin, and Douglas Gale, 2000, Comparing Financial Systems. (MIT Press, Cambridge, Massachusetts).

Allen, Franklin, and Anthony M. Santomero, 1998, The Theory of Financial Intermediation, Journal of Banking and Finance 21, 1461-1485.

Auerbach, Alan J., and Mervyn A. King, 1983, Taxation, Portfolio Choice, and Debt-Equity Ratios: A General Equilbrium Model, Quarterly Journal of Economics 98, 587-610.

Bailey, Martin J., 1969, Capital Gains and Income Taxation, in Arnold C. Harberger and Martin J. Bailey, eds.: The Taxation of Income from Capital (The Brookings Institution, Washington D.C.).

Bell, Leonie, and Tim Jenkinson, 2002, New Evidence on the Impact of Dividend Taxation and on the Identity of the Marginal Investor, Journal of Finance 57, 1321-1346.

Bergstresser, Daniel, and James M. Poterba, 2004, Asset Allocation and Location Decisions: Evidence from the Survey of Consumer Finances, JPubE 88, 1893-1915.

Black, Fisher, and Myron Scholes, 1974, The Effects of Dividend Yield and Dividend Policy on Common Stock Prices and Returns, Journal of Financial Economics 1, 1-22.

Blackburn, Robin, 2002, Banking on Death-Or, Investing in Life: The History and Future of Pensions. (Biddles Ltd, Guildford and King's Lynn, United Kingdom).

Boman, Ragnar, 1982, Ägarstrukturen i börsföretagen (Statens offentliga utredningar (SOU) 1982:28 Stockholm).

Booth, Laurence D., and David J. Johnston, 1984, The Ex-Dividend Day Behavior of Canadian Stock Prices: Tax Changes and Clientele Effects, Journal of Finance 39, 457-476.

Börsch-Supan, Axel, 1994, Savings in Germany-Part I: Incentives, in James M. Poterba, ed.: Public Policies and Household Saving (University of Chicago Press).

Brav, Alon, John R. Graham, Campbell R. Harvey, and Roni Michaely, 2008, Managerial Response to the May 2003 Dividend Tax Cut, Financial Management pp. 611-624.

Brennan, Michael J., 1970, Taxes, Market Valuation and Corporate Financial Policy, National Tax Journal 23, 417-427.

Chay, J.B., Dosoung Choi, and Jeffrey Pontiff, 2006, Market Valuation of Tax-Timing Options: Evidence from Capital Gains Distributions, Journal of Finance 61, 837-866. 
Chetty, Raj, and Emmanuel Saez, 2005, Dividend Taxes and Corporate Behavior: Evidence from the 2003 Dividend Tax Cut, Quarterly Journal of Economics 120, 791-833.

Coffee, John C., 1991, Liquidity versus Control: The Institutional Investor as Corporate Monitor, Columbia Law Review 91, 1277-1368.

Corneo, Giacomo, 2005, The Rise and Likely Fall of the German Income Tax, 1958-2005, CESifo Economic Studies 51, 159-186.

Dahlquist, Magnus, Göran Robertsson, and Kristian Rydqvist, 2009, Direct Evidence of Dividend Tax Clienteles, SSRN working paper.

Dammon, Robert M., Chester S. Spatt, and Harold H. Zhang, 2004, Optimal Asset Location and Allocation with Taxable and Tax-deferred Investing, Journal of Finance 59, 999-1038.

Elton, Edwin J., and Martin J. Gruber, 1970, Marginal Stockholders Tax Rates and the Clientele Effect, Review of Economics and Statistics 52, 68-74.

Fama, Eugene F., and Kenneth R. French, 2002, The Equity Premium, Journal of Finance 57, $637-660$.

Ferreira, Miguel A., and Pedro Matos, 2008, The Colors of Investors' Money: The Role of Institutional Investors Around the World, Journal of Financial Economics 88, 499-533.

FESE, 2007, Share Ownership Structure in Europe, Federation of European Securities Exchanges.

Fougère, Denis, 1994, Public Policies and Household Saving in France, in J. Poterba, ed.: Public Policies and Household Saving (University of Chicago Press).

French, Kenneth R., 2008, Presidential Address: The Cost of Active Investing, Journal of Finance 63, 1537-1573.

Friedman, Benjamin M., 1996, Economics Implications of Changing Share Ownership, Journal of Portfolio Management 22, 59-70.

Grandell, Axel, 1959, Aktiesparande, working paper, Swedish School of Economics (Åbo Akademi).

Green, Richard C., and Burton Hollifield, 2003, The Personal-Tax Advantages of Equity, Journal of Financial Economics 67, 175-216.

Grossman, Sanford J., and Robert J. Shiller, 1981, The Determinants of the Variability of Stock Prices, American Economic Review 71, 222-227.

Howell, David, 2008, The analysis of missing data, In William Outhwaite and S. Turner (eds.), Handbook of Social Science Methodology, London: Sage.

Huang, Jennifer, 2008, Taxable and Tax-Deferred Investing: A Tax-Arbitrage Approach, Review of Financial Studies 21, 2173-2207.

ICI, 2010, Research Fundamentals, Vol. 19, No. 3 (May), Investment Comany Institute.

International Monetary Fund, 2009, International Financial Statistics (IFS). (Washington, D.C.). 
Ippolito, Richard A., 1986, Pensions, Economics, and Public Policy. (Dow Jones-Irwin Homewood Illinois).

Ishi, Hiromitsu, 2001, The Japanese Tax System. (Oxford University Press).

Julio, Brandon, and David Ikenberry, 2004, Reappearing Dividends, Journal of Applied Corporate Finance 16, 89-100.

Karhunen, Jussi, and Matti Keloharju, 2001, Shareownership in Finland 2000, Finnish Journal of Business Economics 50, 188-226.

King, Mervyn A., 1977, Public Policy and the Corporation. (John Wiley \& Sons New York).

Kukkonen, Matti, 2000, Capital Gains Taxation and Realization Behaviour: Evidence from Finish Panel Data, Dissertaion Helsinki School of Economics and Business Administration.

Laakso, J., 1979, Osake, obligaatio ja pörssi, working paper Helsinki School of Economics.

Lakonishok, Joseph, and Theo Vermaelen, 1983, Tax Reform and Ex-Dividend Day Behavior, Journal of Finance 38, 1157-1179.

Litzenberger, Robert H., and Krishna Ramaswamy, 1979, The Effects of Personal Taxes and Dividends on Capital Asset Prices: Theory and Empirical Evidence, Journal of Financial Economics 7, 163-195.

Lucas, Robert E., 1978, Asset Prices in an Exchange Economy, Econometrica 46, 1429-1445.

Mehra, Rajnish, and Edward C. Prescott, 1985, The Equity Premium: A Puzzle, 15, 145-161.

Miller, Merton H., 1977, Debt and Taxes, Journal of Finance 32, 261-275.

Mitchell, B.R., 2007, International Historical Statistics. (Palgrave Macmillan Basingstoke).

Moyle, John, 1971, The Pattern of Ordinary Share Ownership. (Cambridge University Press).

OECD, 2002, Forty Years' Experience with the OECD Code of Liberalisation of Capital Movements. (OECD, Paris).

Orhnial, A. J. H., and L. P. Foldes, 1975, Estimates of Marginal Tax Rates for Dividends and Bond Interest in the United Kingdom, Economica 42, 79-91.

Parks, Richard, 1967, Efficient Estimation of a System of Regression Equations When Disturbances Are Both Serially and Contemporaneously Correlated, Journal of the American Statistical Association $62,500-509$.

Perry, J. Harvey, 1989, A Fiscal History of Canada-The Postwar Years. (Canadian Tax Foundation Toronto).

Perry, J. Harvey, 1990, Taxation in Canada. (Canadian Tax Foundation Toronto).

Piketty, Thomas, 2001, Les hauts revenue en France au XXe siècle-Inégalité et redistributions 1901-1998. (Paris: Grasset). 
Poterba, James M., and Andrew A. Samwick, 1995, Stock Ownership Patterns, Stock Market Fluctuations, and Consumption, BROOK pp. 295-372.

Poterba, James M., and Andrew A. Samwick, 2003, Taxation and Household Portfolio Composition: US Evidence from the 1980s and the 1990s, Journal of Public Economics 87, 5-38.

Protopapadakis, Aris, 1983, Some Indirect Evidence on Effective Capital Gains Tax Rates, Journal of Business 56, 127-138.

Revell, Jack, and John Moyle, 1966, The Owners of Quoted Shares-A Survey for 1963. (Chapman and Hall Ltd London).

Revenue Canada, 1950-2006, Taxation Statistics. (Ottawa, Canada).

Rydqvist, Kristian, Steven T. Schwartz, and Joshua D. Spizman, 2010, The Tax Benefit of Income Smoothing, working paper Binghamton University.

Sagoo, Sumeet, 2005, Facts and Figures on Government Finance 38th Edition. (Tax Foundation Washington, DC).

Sialm, Clemens, 2009, Tax Changes and Asset Pricing, American Economic Review 99, 1356-1383.

Sialm, Clemens, and Laura Starks, 2010, Mutual Fund Tax Clienteles, SSRN working paper.

Söderberg, Hans, 1996, Inkomstskattens utveckling under 1900-talet. En vägvisare för skatteberäkningar åren 1921-1996. (Skattebetalarnas förening Stockholm).

Spånt, Roland, 1975, Förmögenhetsfördelningen i Sverige. (Prisma Stockholm).

Tax Bureau of Finance, 1953-2005, An Outline of Japanese Taxes. (Tax Bureau, Ministry of Finance Tokyo). 


\section{A Appendix: Aggregate Stock and Bond Ownership Data}

In this Appendix, we report additional data sources and variable definitions used in Section 2.1 . Aggregate stock market ownership data for the United States is reported in the Flow of Funds, Table L.213. Aggregate bond ownership is spread out over four tables. To calculate bond ownership, we combine bond holdings from tables L.209 (Treasury Securities), L.210 (Agency- and GSE-Backed Securities), and L.212 (Corporate and Foreign Bonds). We exclude municipal bonds (Table L.211), and we subtract "Savings bonds" from Table L.209. We then combine a number of series within each table to calculate our specific ownership categories. Mutual Funds combines "Money market mutual funds" and "Mutual funds" from Tables L.209, L.210, and L.212 as well as "Closed-end funds" and "Exchange-traded funds" from Tables L.209 and L.212. Pension Funds combines "Private pension funds," "State and local govt. retirement funds," and "Federal government retirement funds". Insurance is composed of of "Life insurance companies", but we exclude "Property-casualty insurance companies".

Figure A1: Pension Fund Assets Invested in Mutual Funds

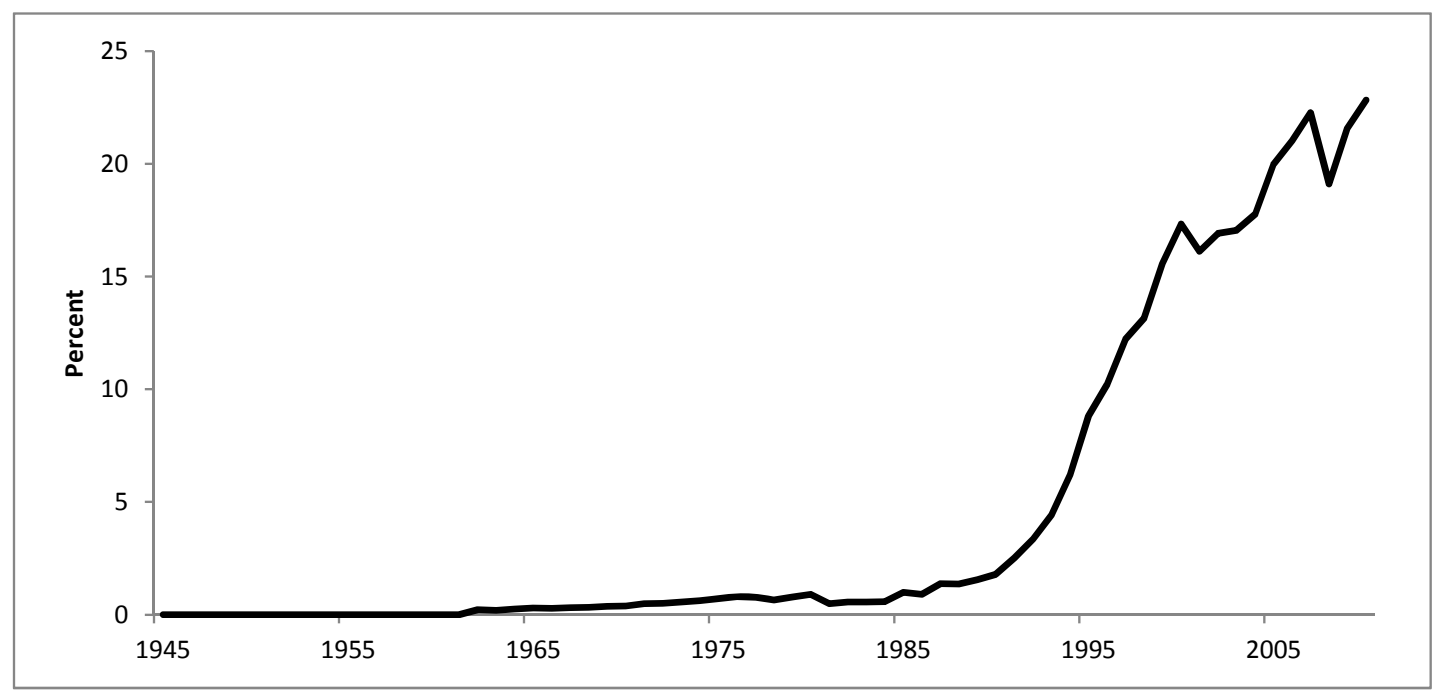

The figure reports the percent of U.S. pension fund assets that are invested in mutual funds. Data source: Flow of Funds.

The aggregate balance sheet of pension funds can be constructed from combining Tables L.118 (Private Pension Funds), L.119 (State and Local Government Employee Retirement Funds), and 
L.120 (Federal Government Retirement Funds). Stocks are identified as "Corporate equities", and fixed income securities as "Credit market instruments", "Checkable deposits and currency," "Time and savings deposits,", and "Money market fund shares". Pension funds also hold mutual fund shares and miscellaneous other assets. The evolution of the pension fund holdings of mutual fund shares can be sees in Figure A1. A growing share of pension fund asset management is outsourced to the mutual fund industry.

\section{B Appendix: Personal Taxation of Stocks}

This appendix explains the principles of personal taxation of income from stocks in the United States, Canada, United Kingdom, Japan, Germany, France, Sweden, and Finland. We do not cover the taxation of corporate income except where it is needed to understand personal taxation of dividends. The following general notation is used:

$$
\begin{aligned}
\tau_{d} & =\text { personal tax rate on dividend income. } \\
\tau_{r} & =\text { reduction rate on dividend income. } \\
\tau_{i} & =\text { imputation rate on dividend income. } \\
\tau_{g} & =\text { personal tax rate on capital gains. } \\
\tau_{p} & =\text { personal tax rate on ordinary income. } \\
\tau_{p i} & =\text { personal tax rate on investment income. } \\
\tau_{p c} & =\text { central personal tax rate. } \\
\tau_{p s} & =\text { sub-central personal tax rate. } \\
\tau_{s c} & =\text { central surtax rate on personal tax. } \\
\tau_{s s} & =\text { sub-central surtax rate on personal tax. }
\end{aligned}
$$

The precise meaning of each tax rate is explained in its context below. Many tax systems are covered and additional notation is introduced as needed. The statutory tax rate data are not reported here, but can be requested from the authors. 


\section{B.1 United States}

Personal income is subject to federal, state, and city taxes. When there is a choice (since 1949), we choose the federal tax tables for a married couple filing jointly. We adjust for state tax by assuming it is a time-series constant $\tau_{p s}=5 \%$, but we ignore city tax. The assumption for the state tax rate is based on the equally-weighted average top statutory state tax rates in 1950, 1987, and 2006 . The information is taken from Sagoo (2005).

\section{B.1.1 Dividends}

From 1913-2002, dividends are taxed as ordinary income. State taxes are deductible at the federal level, so the marginal tax rate on dividend income equals:

$$
\tau_{d}=\tau_{p c}\left(1-\tau_{p s}\right)+\tau_{p s}
$$

where $\tau_{p c}$ is the federal tax rate and $\tau_{p s}$ the state tax rate. In 2003, the United States switches to a dual-income system, where ordinary income and investment income are taxed as separate income classes. The marginal tax rate on dividends is:

$$
\tau_{d}=\tau_{p i}\left(1-\tau_{p s}\right)+\tau_{p s}
$$

where $\tau_{p i}$ is the dividend tax rate.

\section{B.1.2 Capital Gains}

Capital gains taxation of stocks begins in 1916. From 1916-1933, realized capital gains on stocks are taxed as ordinary income. From 1922-1933, the capital gains tax rate is capped at $12.5 \%$. From 1934-1986, a portion $\pi$ of long-term capital gains is taxed:

$$
\tau_{g}=\pi \times\left[\tau_{p c}\left(1-\tau_{p s}\right)+\tau_{p s}\right]
$$


The inclusion portion $\pi$ varies over time. The federal capital gains tax rate is capped at $30 \%$ (1938-1941) and 25\% (1942-1969). The cap is removed in 1972-1986. There is a Vietnam war capital gains surtax $\tau_{s g}$ in $1968-1970$ :

$$
\tau_{g}=\pi \times\left[\tau_{p c}\left(1+\tau_{s g}\right)\left(1-\tau_{p s}\right)+\tau_{p s}\right]
$$

Since 1987, long-term capital gains are taxed as a separate income class:

$$
\tau_{g}=\tau_{p i}\left(1-\tau_{p s}\right)+\tau_{p s}
$$

where $\tau_{p i}$ is the long-term capital gains tax rate.

\section{B.2 Canada}

A distinguishing feature of the Canadian tax system is that provincial (sub-central) tax rates are defined as proportions of federal (central) taxes. Hence, central and sub-central tax rates are multiplied with each other, which means that the provincial tax is a tax on the federal tax. We approximate the provincial tax with the rates from Ontario. Our main data sources are Revenue Canada (1950-2006), Perry (1989), and Perry (1990) 35

\section{B.2.1 Dividends}

We begin with the Canadian tax system in 1949-1971. A tax credit is provided at the central level for sub-central taxes. Let $\tau_{r s}$ denote the sub-central reduction rate. The personal tax rate net of the sub-central tax credit equals:

$$
\tau_{p}=\tau_{p c}+\left(\tau_{p s}-\tau_{r s}\right) \tau_{p c}
$$

\footnotetext{
${ }^{35}$ We would like to thank particularly Alan Macnaughton of the University of Waterloo for carefully checking the details of our analysis of the Canadian tax code.
} 
Dividends are taxed as personal income, but Canada offers a dividend-tax relief at rate $\tau_{r}$. Dividend income is taxed at the rate:

$$
\begin{aligned}
\tau_{d} & =\tau_{p c}-\tau_{r} & & (\text { central tax }) \\
& +\left(\tau_{p s}-\tau_{r s}\right) \times\left(\tau_{p c}-\tau_{r}\right) & & (\text { sub-central tax })
\end{aligned}
$$

This expression corrects Lakonishok and Vermaelen (1983) and Booth and Johnston (1984), who include the sub-central tax credit, but fail to include the sub-central tax.

We proceed with the tax system in 1972-1999. There are two important changes. First, an imputation-tax credit at rate $\tau_{i}$ replaces the dividend-reduction rate $\tau_{r}$. The dividend tax and the imputation-tax credit are levied on the grossed-up dividend $1+g$. Second, the sub-central tax credit is abandoned and, later, surtaxes are added at both the central and the sub-central level. The surtaxes are defined as proportions of other taxes. Dividend income is taxed at rate:

$$
\begin{aligned}
\tau_{d} & =\left[(1+g) \tau_{p c}-(1+g) \tau_{i}\right] & & (\text { central tax }) \\
& +\left[(1+g) \tau_{p c}-(1+g) \tau_{i}\right] \times \tau_{s c} & & (\text { central surtax }) \\
& +\left[(1+g) \tau_{p c}-(1+g) \tau_{i}\right] \times \tau_{p s} & & \text { (sub-central tax) } \\
& +\left[(1+g) \tau_{p c}-(1+g) \tau_{i}\right] \times \tau_{p s} \times \tau_{s s} & & \text { (sub-central surtax) }
\end{aligned}
$$

This expression can be simplified to:

$$
\tau_{d}=(1+g)\left(\tau_{p c}-\tau_{i}\right)\left[1+\tau_{p s}\left(1+\tau_{s s}\right)+\tau_{s c}\right]
$$

The personal tax rate is simpler as there is no imputation-tax credit:

$$
\tau_{p}=\tau_{p c}\left[1+\tau_{p s}\left(1+\tau_{s s}\right)+\tau_{s c}\right]
$$

Next, we explain the Canadian tax system as of 2000-2005. This tax reform changes the subcentral tax. Instead of a tax on tax, the sub-central tax becomes a tax on income. Surtaxes remain 
to be tax on tax. A new sub-central dividend credit at rate $\tau_{r s}$ is also introduced:

$$
\begin{aligned}
\tau_{d} & =\left[(1+g) \tau_{p c}-(1+g) \tau_{i}\right] & & (\text { central tax }) \\
& +\left[(1+g) \tau_{p c}-(1+g) \tau_{i}\right] \times \tau_{s c} & & (\text { central surtax }) \\
& +\left[(1+g) \tau_{p s}-(1+g) \tau_{r s}\right] & & (\text { sub-central tax }) \\
& +\left[(1+g) \tau_{p s}-(1+g) \tau_{r s}\right] \times \tau_{s s} & & \text { (sub-central surtax) }
\end{aligned}
$$

Essentially, the federal and provincial taxes are calculated separately and then summed together. The expression simplifies to:

$$
\tau_{d}=(1+g)\left[\left(\tau_{p c}-\tau_{i}\right)\left(1+\tau_{s c}\right)+\left(\tau_{p s}-\tau_{r s}\right)\left(1+\tau_{s s}\right)\right]
$$

Again, the personal tax rate is simpler:

$$
\tau_{p}=\tau_{p c}\left(1+\tau_{s c}\right)+\tau_{p s}\left(1+\tau_{s s}\right)
$$

\section{B.2.2 Capital Gains}

Capital gains taxation of stocks begins in 1972. The principles have not changed as of 2006. A proportion of long-term capital gains $\pi$ is taxed as ordinary income:

$$
\tau_{g}=\pi \times \tau_{p}
$$

From 1986-1989, households earn a lifetime capital gains exemption for the sale of all property including real estate. Although the exemption amount is quite large, we ignore this provision.

\section{B.3 United Kingdom}

Income taxes are collected at the central level only, so we do not need to worry about sub-central taxes. The main information and data sources are Orhnial and Foldes (1975), King (1977), and the HM Revenue \& Customs website (http://www.hmrc.gov.uk/index.htm). 


\section{B.3.1 Dividends}

From 1947-1964, the United Kingdom has a tax system which can be characterized as a hybrid of two business taxation models. One component conforms to the classical model of corporate taxation with double taxation except that there are different tax rates for distributed and retained profits. Specifically, the corporation pays corporate tax at rate $\tau_{c d}$ on distributed profits and rate $\tau_{c r}$ on retained profits, where $\tau_{c d} \geq \tau_{c r}$. Shareholders in higher income brackets pay personal tax on dividends at rate $\tau_{p}-\tau_{p s t}$, where $\tau_{p s t}$ is the standard rate of income tax. The other component of the hybrid system conforms to the standard model of partnership taxation, where business income passes through and is taxed as personal income. Specifically, shareholders pay tax on corporate income at the standard rate of income tax $\tau_{p s t}$ irrespective of whether corporate income is paid out or retained. This tax is paid in addition to personal tax on dividends.

In the hybrid system, the marginal tax rate on dividend income equals the personal rate. To see this, we decompose pre-tax corporate income $Y$ into after-tax dividend $D$, after-tax retained earnings $R E T$, paid corporate taxes on dividends, and paid corporate taxes on retained earnings:

$$
Y=D+\tau_{c d} D+R E T+\tau_{c r} R E T \text {. }
$$

From 1947-1951, an individual shareholder is liable for personal tax in the amount:

$$
\left(\tau_{p}-\tau_{p s t}\right) D+\tau_{p s t} D+\tau_{p s t} R E T
$$

The first term is personal income tax on dividends (first component of the hybrid system). The second and the third terms are personal tax on corporate income (second component). From this expression, we can see that the marginal tax rate on dividend income equals:

$$
\tau_{d}=\left(\tau_{p}-\tau_{p s t}\right)+\tau_{p s t}=\tau_{p}
$$

From 1952-1964, the corporate tax deductability is removed and shareholders are also liable for 
personal tax on paid corporate taxes:

$$
\left(\tau_{p}-\tau_{p s t}\right) D+\tau_{p s t} D+\tau_{p s t} R E T+\tau_{p s t}\left(\tau_{c d} D+\tau_{c r} R E T\right) .
$$

We can see that the marginal tax rate on dividend income equals the marginal tax rate on personal income as in (B17).

In 1965-1972, the United Kingdom switches to a classical tax system. Dividends are taxed as personal income at rate $\tau_{d}=\tau_{p}$. A few years later, in 1973-1998, the United Kingdom switches to an imputation-tax system with a significant dividend-tax relief. The tax and the imputation-tax credit is levied on the grossed-up dividend $1 /\left(1-\tau_{i}\right)$, so the marginal tax rate on dividend income equals:

$$
\tau_{d}=\frac{\tau_{p}-\tau_{i}}{1-\tau_{i}}
$$

The imputation rate is defined as the standard rate of income tax, which means that only households in higher income brackets pay tax on dividends. From 1973-1984, dividend income above an exclusion amount is subject to investment income surcharge at rate $15 \%$ on top of the ordinary income tax rate for high-income earners. We ignore the surcharge in our calculations because the exclusion amount is large.

Since 1999, the United Kingdom combines the imputation-tax system with a dual-income system where dividends are taxed as a separate income class at a proportional rate below ordinary income:

$$
\tau_{d}=\frac{\tau_{p i}-\tau_{i}}{1-\tau_{i}}
$$

\section{B.3.2 Capital Gains}

Capital gains taxation of stocks begins in 1965. From 1965-1987, the United Kingdom practices a dual-income system where realized capital gains are subject to a proportional rate after an initial exempt amount. From 1988-2006, realized capital gains are taxed as ordinary income except for an initial exempt amount. From 1982-1997, the cost basis is indexed for inflation with values provided in a table. The gap plot for the United Kingdom in Figure 6a is corrected for indexing. 


\section{B.3.3 Pensions}

From 1973-1997, untaxed investors also earn a tax refund on dividends (see Bell and Jenkinson (2002)). This means that equation (3) for the expected rate of return on a pension fund changes to:

$$
r \approx\left(1+\frac{\tau_{i}}{1-\tau_{i}}\right) d+g
$$

and equation (5) becomes:

$$
\operatorname{GAP}=\frac{\left(\frac{\tau_{p}}{1-\tau_{i}}\right) d+\tau_{g} g}{1+i}
$$

\section{B.4 Japan}

Taxes are collected at the central level, but the revenues from specific taxes are reserved for the sub-central administration. The central tax is referred to as national tax and the sub-central taxes as prefectural tax and municipal tax, respectively. From 1953-1961, municipalities are offered the choice among three different tax schedules. We focus on option $b$ which becomes the standard from 1962. The main data sources are Ishi (2001) and Tax Bureau of Finance (1953-2005). We are missing the tax tables from 1949-1952 36

\section{B.4.1 Dividends}

Dividend income is taxed as personal income subject to central tax rate $\tau_{p c}$ and sub-central tax rate $\tau_{p s}$ (prefectural and municipal tax). Both the central and the sub-central tax schedules are progressive. From 1950-2006, Japan offers a dividend-tax credit in the form of a rate reduction. The central reduction rate is $\tau_{r c}$ and the sub-central reduction rate $\tau_{r s}$. The marginal tax rate on dividend income equals:

$$
\tau_{d}=\tau_{p c}+\tau_{p s}-\tau_{r c}-\tau_{r s}
$$

The reduction rates are lower for higher dividend income (two income brackets). In our calculations, we choose the reduction rate for the lower income level because the higher income tax bracket is

\footnotetext{
${ }^{36}$ We would like to thank particularly Chihiro Shima of the Development Bank of Japan for help with understanding the Japanese tax code.
} 
high (annual dividend income above JPY 10 million, approximately USD 100,000). The marginal tax rates on personal income $\tau_{p c}+\tau_{p s}$ is capped from 1961-1988:

$$
\tau_{d}=\min \left[\tau_{p c}+\tau_{p s}, \tau_{c a p}\right]-\tau_{r c}-\tau_{r s}
$$

i.e., the dividend-tax reduction is earned in full after the cap is imposed.

From 1965-2006, the marginal tax rate on dividends depends on the dividend amount earned from each stock in the portfolio. Therefore, the marginal tax rate does not only depend on household income but also on portfolio composition and dividend yield. The dividend is small, intermediate, or large depending on whether the dividend on the stock falls below, between, or exceeds JPY 50,000 and 250,000, respectively. In 1973, the cutoffs are doubled. From 1965-1988, large dividends are taxed according to $\mathrm{B} 23$. This tax treatment referred to as Case I in Figure 5a and the text above. For intermediate dividends, the shareholder can choose between personal taxation (B23) and the following simplified procedure:

$$
\tau_{d}=\tau_{p i}+\tau_{p s}-\tau_{r s}
$$

Under the option, a proportional investment tax $\tau_{p i}$ replaces the central tax schedule $\tau_{p c}$ and reduction $\tau_{r c}$. The option is referred to as Case II above. Finally, for small dividends, the shareholder can choose between personal taxation (B23) and not reporting the dividend income on the tax return. In the latter case, the shareholder ends up paying the proportional withholding tax collected at source. This is referred to as Case III above.

\section{B.4.2 Capital Gains}

Before 1953, capital gains on stocks are taxed as ordinary income. From 1953-1988, stocks are exempt from capital gains tax. Capital gains tax on stocks is reintroduced in 1989. For long-term capital gains defined by the minimum holding period of one year, shareholders are given a choice. First, the investor can choose to not report the capital gain. In this case, the capital gains tax equals the withholding tax of $1 \%$ of the sales price. Second, if the investor chooses to report the capital gain on the tax return, it is subject to a proportional investment income tax (national tax 
and local inhabitants tax). We ignore capital gains tax in our calculations.

\section{B.5 Germany}

Personal income is taxed at the central level only. We choose the tax schedule for a married couple filing jointly. From 1958-2006, there is only one tax schedule. Then, the tax for a married couple equals two times the tax on half the income, so the marginal tax rate for a married couple with income equal to GDP5 equals the marginal tax rate of a single filer with income equal to GDP2.5. The main data sources are Börsch-Supan (1994), Corneo (2005), and the German Tax Administration. We use the 1954 tax table for 1955 and 1956, which are missing 37

\section{B.5.1 Dividends}

Dividends are taxed as personal income. A special feature of the German tax code since 1958 is that the tax liability function is determined by a step function in the lowest and highest income brackets and a polynomial in the intermediate income brackets which, for married filing jointly, generalizes to:

$$
T(Y)=2\left[a+b_{1}\left(\frac{0.5 Y-c}{d}\right)+b_{2}\left(\frac{0.5 Y-c}{d}\right)^{2}+b_{3}\left(\frac{0.5 Y-c}{d}\right)^{3}+b_{4}\left(\frac{0.5 Y-c}{d}\right)^{4}\right]
$$

where $Y$ denotes taxable income and $\left\{a, b_{1}, b_{2}, b_{3}, c, d\right\}$ are parameters which vary over time. Taking the first derivative of the tax liability function gives us the marginal tax rate function for the intermediate income brackets:

$$
\tau_{p}=\frac{1}{d}\left[b_{1}+2 b_{2}\left(\frac{0.5 Y-c}{d}\right)+3 b_{3}\left(\frac{0.5 Y-c}{d}\right)^{2}+4 b_{4}\left(\frac{0.5 Y-c}{d}\right)^{3}\right]
$$

The polynomial function has three terms in 1958-1974, four terms in 1975-1989 (as shown), and two terms in 1990-2006 (linear function).

From 1977-2001, Germany has an imputation-tax system that works as in the United Kingdom, Equation (B19). From 2002-2006, Germany switches to a partial-inclusion system, where a

\footnotetext{
${ }^{37}$ We would like to thank particularly Sebastian Herzog of the University of Mannheim for help with understanding the German tax code.
} 
proportion $\pi$ of the dividend is taxable income:

$$
\tau_{d}=\pi \times \tau_{p}
$$

Following the unification of West and East Germany, personal income is also subject to a multiplicative surtax:

$$
\tau_{d}= \begin{cases}\left(\frac{\tau_{p}-\tau_{i}}{1-\tau_{i}}\right)\left(1+\tau_{s c}\right) & , \text { in } 1990-2001 \\ \pi \tau_{p}\left(1+\tau_{s c}\right) & , \text { in } 2002-2006\end{cases}
$$

From 1950-2006, there is also a church tax which also enters like a multiplicative surtax. We ignore this tax. The church tax is optional (one can opt out of the church), the effective tax rate is relatively small in the order of $1-2 \%$, and it varies geographically.

\section{B.5.2 Capital Gains}

Long-term capital gains defined by a minimum holding period of six months before 1998 and 12 months from 1998 are exempt from capital gains tax.

\section{B.6 France}

Taxes are collected at the central level only. We ignore surtaxes in our calculations. The main data sources are Fougère (1994) and Piketty (2001).

\section{B.6.1 Dividends}

From 1950-1959, dividends are taxed at source at rate $\tau_{w}$. The net dividend is taxed as personal income:

$$
\tau_{d}=1-\left(1-\tau_{p}\right)\left(1-\tau_{w}\right)
$$

From 1960-1964, dividends are taxed as personal income. The withholding tax is fully deductible:

$$
\tau_{d}=\tau_{p} .
$$


From 1965-2004, France has a standard imputation-tax system that offers a partial credit for corporate taxes on distributed profits as in (B19). In 2005-2006, France replaces the imputationtax system with a partial-inclusion system where a proportion $\pi$ of the dividend is taxed as personal income as in (B28).

\section{B.6.2 Capital Gains}

Capital gains taxation of stocks begins in 1976. Capital gains are taxed as a separate income class subject to a low proportional rate. A relatively large amount is exempt, so we assume that the capital gains tax is effectively zero.

\section{B.7 Sweden}

Personal income is subject to national tax (central), municipal tax, and church tax (sub-central). We use the average municipal tax rate, but we ignore the prefectural tax and the church tax, which are relatively small. We also ignore a social security tax (Folkpensionsavgift, 1936-1973), which is based on ordinary income including investment income. The social security tax is capped and rather small at higher income levels. When there is a choice (1953-1970), we use the national tax rates for a married couple filing jointly. The main data sources are Söderberg (1996), Statistics Sweden, and the Swedish Tax Administration.

\section{B.7.1 Dividends}

Dividends are taxed as personal income. Sub-central taxes are deductible before 1971 and not deductible from 1971:

$$
\tau_{d}= \begin{cases}\tau_{p c}\left(1-\tau_{p s}\right)+\tau_{p s} & , \text { in } 1948-1970 \\ \tau_{p c}+\tau_{p s} & , \text { in } 1971-1990\end{cases}
$$

The combined marginal tax rate is capped in 1980-1985. In 1991, Sweden introduces a dual-income system, where ordinary income is subject to a progressive schedule and dividend income is taxed as investment income subject to a lower proportional rate:

$$
\tau_{d}=\tau_{p i}
$$




\section{B.7.2 Capital Gains}

Capital gains taxation of stocks begins in 1910. From 1910-1951, short-term capital gains as defined by a holding period of less than five years are taxed as ordinary income, while long-term capital gains are exempt. From 1952-1976, a portion $\pi$ of short-term capital gains is taxed as ordinary income as in (B14). The portion depends on the holding period:

$$
\pi=\left\{\begin{aligned}
100 \% & \text {, if } 0-2 \text { years, } \\
75 \% & \text {, if } 2-3 \text { years, } \\
50 \% & \text {, if } 3-4 \text { years } \\
25 \% & , \text { if } 4-5 \text { years } \\
0 \% & , \text { if }>5 \text { years }
\end{aligned}\right.
$$

From 1967-1976, 10\% of the sales price of a security held more than five years is taxed as ordinary income. From 1977-1989, the formula for the inclusion proportion changes to:

$$
\pi=\left\{\begin{aligned}
100 \% & , \text { if } 0-2 \text { years } \\
40 \% & , \text { if }>2 \text { years }
\end{aligned}\right.
$$

In 1990, the proportion increases to $\pi=50 \%$. From 1991-2006, all capital gains are taxed as investment income:

$$
\tau_{g}=\tau_{p i}
$$

The tax rule in effect 1967-1976 removes the basis from the calculation of the long-term capital gain. As above, let $g$ denote nominal stock price growth rate. The statutory marginal tax rate on long-term capital gains equals:

$$
\tau_{g}=0.10 \tau_{p}\left(\frac{(1+g)^{N}}{(1+g)^{N}-1}\right)
$$

This expression shows that the effect on the marginal tax rate from the loss of the basis is small over long investment horizons, especially when expected stock price growth is high. The value of 
the basis protection disappears in the limit as $N$ goes to infinity. In the analysis above, we assume that $N=15, g=2 \%+i$, where $i$ equals three-year moving average inflation.

\section{B.7.3 Pensions}

From 1991-2006, imputed income from pension asset management defined as the average treasury rate during the previous year times the value of the pension assets in the beginning of the year is taxed at the proportional rate $15 \%$. We denote $r_{f}$ as the expected treasury rate with and measure it as $1 \%$ plus moving average inflation. Equation (5) becomes:

$$
\mathrm{GAP}=\frac{\tau_{d} d+\tau_{g} g-0.15 r_{f}}{1+i}
$$

\section{B.8 Finland}

Income taxation in Finland resembles Sweden in many ways. Personal income is subject to national tax (central), municipal tax, and church tax (sub-central). We approximate the sub-central tax rate with the average municipal tax rate, but we ignore the relatively small church tax. We use the national tax tables for a married couple filing jointly with no dependents (1950-1975). The main data sources are Kukkonen (2000) and the Finnish Tax Administration.

\section{B.8.1 Dividends}

From 1950-1992, dividends are taxed as ordinary income. The marginal tax rate on dividends equals the sum of central and sub-central tax rates:

$$
\tau_{d}=\tau_{p c}+\tau_{p s}
$$

From 1993-2004, Finland uses a dual-income system with full imputation. Dividends are subject to investment income tax at rate $\tau_{p i}$ and corporate tax is credited back through imputation as in the United Kingdom, Equation (B19). Most years, the investment income rate equals the imputation rate so that $\tau_{d}=0$. Recently, in 2005-2006, Finland replaces the imputation system with a partial- 
inclusion system such that a proportion $\pi$ of the dividend is taxed as investment income:

$$
\tau_{d}=\pi \times \tau_{p i}
$$

\section{B.8.2 Capital Gains}

Capital gains taxation of stocks begins in 1920. From 1920-1985, short-term capital gains as defined by a holding period of less than five years are taxed as ordinary income, while long-term capital gains are exempt. From 1986-1992, the rules change gradually towards the new system in place since 1993. An initial (large) amount is tax exempt. A portion $\pi$ of the capital gain above the tax-exempt amount is taxed as ordinary income as in (B14). The portion depends on the holding period. From 1986-1988 it is:

$$
\pi=\left\{\begin{aligned}
100 \% & , \text { if } 0-5 \text { years } \\
20 \% & , \text { if }>5 \text { years }
\end{aligned}\right.
$$

from 1989-1990:

$$
\pi=\left\{\begin{aligned}
100 \% & , \text { if } 0-4 \text { years } \\
80 \% & , \text { if } 4-5 \text { years } \\
40 \% & , \text { if }>5 \text { years }
\end{aligned}\right.
$$

and from 1991-1992:

$$
\pi=\left\{\begin{aligned}
100 \% & , \text { if } 0-4 \text { years } \\
80 \% & , \text { if } 4-5 \text { years } \\
50 \% & , \text { if }>5 \text { years. }
\end{aligned}\right.
$$

From 1993-2006, all capital gains on stocks are taxed as investment income as in (B36). Since 1986, a long-term investor has the option to define the capital gain as $50 \%$ of the sales price from 1986-1992 and 30\% from 1993-2006. In our calculations, we ignore this option and the initial tax-exempt amount because the difference is small. 